\title{
Reorganization of Neural Peptidergic Systems in the Median Eminence after Hypophysectomy
}

\author{
Marcelo J. Villar, Björn Meister, and Tomas Hökfelt \\ Department of Neuroscience, The Berzelius Laboratory, Karolinska Institutet, Stockholm, 17177 Sweden
}

Earlier studies have shown the formation of a novel neural lobe after hypophysectomy, an experimental manipulation that causes transection of neurohypophyseal nerve fibers and removal of pituitary hormones. The mechanisms that underly this regenerative process are poorly understood.

The localization and number of peptide-immunoreactive (-IR) fibers in the median eminence were studied in normal rats and in rats at different times of survival after hypophysectomy using indirect immunofluorescence histochemistry. The number of vasopressin (VP)-IR fibers increased in the external layer of the median eminence in $5 \mathrm{~d}$ hypophysectomized rats. Oxytocin (OXY)-IR fibers decreased in the internal layer and progressively extended into the external layer. At long survival times ( 9 and 16 months) both VP- and OXY-IR fibers had a bilayered distribution occupying both the external and internal layers. Double-labeling experiments combining VP and tyrosine hydroxylase antisera as well as $O X Y$ and growth hormone-releasing factor antisera showed that injured neurosecretory fibers growing into the external layer displaced fibers from parvocellular cells originally located there. As a result, there was essentially an inversion in the distribution of these fibers within the median eminence. Galanin (GAL)- and cholecystokinin (CCK)-IR fibers exhibited a similar pattern of distribution after the lesion. Thus, after $5 \mathrm{~d}$ there was an increase in GAL- and CCKIR fibers in the internal layer. At 14 and $30 \mathrm{~d}$, the number of GAL- and CCK-IR fibers progressively decreased, but after longer survivals ( 9 and 16 months) there was a dramatic reappearance. Dynorphin (DYN)-LI showed a dramatic increase at all levels of the median eminence at short survival times after hypophysectomy, followed by a subsequent de-

\footnotetext{
Received Jan. 12, 1994; revised Mar. 16, 1994; accepted Mar. 29, 1994.

This work was supported by the Swedish MRC (04X-10358, 04X-2887), the National Institute of Ageing (AG 10491), Marianne and Marcus Wallenbergs Stiftelse, Fredrik and Ingrid Thuring Stiftelse, Åke Wibergs Stiftelse, the Swedish Tercentenary Bank Foundation, Konung Gustav V:s and Drottning Victorias Stiftelse, Magnus Bergvalls Stiftelse, Tore Nilsons Stiftelse, the Wenner Gren Center Foundation (M.J.V.), and research funds of the Karolinska Institute. M.J.V. is an established investigator of the National Research Council in Argentina. For the generous supply of antisera we express sincere gratitude to Professors R. Elde, Minnesota University, MN(VP); J. Fahrenkrug, Bispebjerg Hospital, Copenhagen Denmark (VIP, PHI); P. Frey, Sandoz Research Institute, Bern, Switzerland (CCK) M. Goldstein, New York University Medical Center, NY (TH); M. Morris, Wake Forest University, Winston-Salem, NC (OXY); L. Terenius, Karolinska Institute Stockholm, Sweden (DYN); J. Walsh, University of California, Los Angeles, CA (monoclonal CCK); and H. Gainer, NIH, Bethesda, MD (monoclonal OXY-NP)

Correspondence should be addressed to Björn Meister, M.D., Ph.D., at the above address.
}

Copyright (C) 1994 Society for Neuroscience $0270-6474 / 94 / 145996-17 \$ 05.00 / 0$ crease to a final stage of a few, strongly immunoreactive fibers in the external layer at longer survival times. Vasoactive intestinal polypeptide (VIP)- and peptide histidineisoleucine (PHI)-IR fibers in hypophysectomized animals had already contacted portal vessels $5 \mathrm{~d}$ after hypophysectomy, and from then on progressively increased in numbers. Finally, most of the peptide fibers described above formed dense innervation patterns around the large blood vessels along the lateral borders of the median eminence.

The present results show that hypophysectomy induces a wide variety of changes in hypothalamic neurosecretory fibers. Not only is the expression of several peptides in these fibers modified following different survival times, but a reorganization of the distribution of immunoreactive fibers within the median eminence is demonstrated. The hypothesis is raised that regeneration of injured neurosecretory fibers may be dependent on changes in the expression of peptides possessing trophic actions.

[Key words: regeneration, neurohypophysis, neuropeptide, plasticity, trophic factor, supraoptic nucleus, paraventricular nucleus, hypophysectomy, galanin, cholecystokinin, dynorphin, vasopressin, oxytocin, vasoactive intestinal polypeptide, peptide histidine-isoleucinel

The hypothalamic magnocellular neurosecretory system consists of a group of peptidergic neurons distributed in the paraventricular (PVN) and supraoptic (SON) nuclei and some basal accessory cclls, all of which project to the neural lobe of the hypophysis (for review, see Brownstein et al., 1980; Silverman and Zimmerman, 1983; Swanson and Sawchenko, 1983). The most important peptides in this system are vasopressin (VP) and oxytocin (OXY), which are released into blood vessels to exert a wide variety of actions, the best-established ones being related to water balance through VP and milk ejection and uterine contraction induced by OXY (for review, see Sawchenko and Swanson, 1985; Leng and Bicknell, 1986; Cunningham and Sawchenko, 1991; Reeves and Andreoli, 1992; Young, 1992).

The magnocellular hypothalamic cells show a remarkable capacity for regeneration even in adult animals. Although many of these neurons both in the PVN and SON are known to degenerate after hypophysectomy or stalk transection (Rasmussen, 1940; Frykman, 1942; Bodian and Marsen, 1951; Billenstein and Léveque, 1955; Moll and De Wied, 1962; Raisman, 1973; Antunes et al., 1980; Burlet et al., 1983; Herman et al., 1986, 1987), surviving neurons may, under certain conditions, generate a "new" neural lobe by sprouting of their projections at the level of the external layer of the median eminence and the 
proximal stump of the pituitary stalk (Stutinsky, 1951; Dellman, 1973; Raisman, 1973). The mechanisms by which injured magnocellular cells undergo degenerative or regenerative processes remain unknown. However, there are results suggesting that very little axonal regeneration occurs at the lesion site, when transection of the axons are performed within the hypothalamus (Danilova and Polenov, 1977; Scott and Knigge, 1981; Nagy et al., 1983; Dellman et al., 1987; Dellman and Carithers, 1992). These results have led to the idea that fibers and terminals from magnocellular cells need a special microenvironment in order to regenerate after lesion, and this may be in part provided by fenestrated blood vessels and pituicytes (Dellman et al., 1988; Carithers and Dellman, 1992; Dellman and Carithers, 1992). In this way, it has been hypothesized that a so far unknown trophic factor(s) could promote regenerative processes (Dellman and Carithers, 1992). A complementary hypothesis could be that after injury neurosecretory neurons may also activate internal mechanisms in order to produce trophic molecules that will promote their survival. One possible group of compounds involved in such processes may be not only classic growth factors but also neuropeptides (see Strand et al., 1992). In addition, it is also possible that the synthesis of substances not necessary during these stages could be turned off.

In addition to VP and OXY, magnocellular cells also co-store a number of bioactive substances, although their functional significance often still is unclear (see Brownstein and Mezey, 1986; Meister et al., 1990; Meister, 1993). Changes in the expression of several of these molecules in magnocellular hypothalamic neurons after injury have been reported previously. Transient increases in VP-, OXY-, galanin (GAL)-, cholecystokinin (CCK)-, dynorphin (DYN)-, vasoactive intestinal polypeptide (VIP)-, peptide histidine-isoleucine (PHI)-, and c-fos-like immunoreactivities (LIs) have been observed in neurons of the PVN and SON nuclei after hypophysectomy or stalk transection (Meister et al., 1990; Villar et al., 1990, 1991a; Young et al., 1990; Ceccatelli et al., 1991). In parallel experiments using in situ hybridization VP, GAL, CCK, and VIP mRNAs were also increased, whereas DYN and OXY mRNA levels were decreased (Villar et al., 1990; Young et al., 1990; Ceccatelli et al., 1991). There are also data indicating an induction of OXY synthesis and a small reduction in VP formation in magnocellular neurons as measured by ${ }^{35} \mathrm{~S}$-cysteine incorporation after hypophysectomy (Wetsel and Fernstrom, 1987), and the levels of OXY have been reported to increase in the PVN after neurointermediate lobectomy (Johnston et al., 1990). As discussed by Cunningham and Sawchenko (1991), these peptides coexisting with VP and OXY are normally present in comparatively low concentrations and may mainly have local autocrine and paracrine actions in the posterior pituitary (Bicknell, 1985; Bondy et al., 1988, 1989). However, in view of earlier (Villar et al., 1990) and present findings roles possibly related to survival/ regencrative mechanisms should perhaps also be considered.

The present study represents a continuation of the analysis of our changes in peptide expression in magnocellular hypothalamic neurons after nerve injury here focusing on adaptive, long-term changes. By means of immunocytochemistry, we have analyzed the reorganization of neurosecretory fibers after shortand long-term hypophysectomy. The results show a wide variety of changes, not only in the number and distribution of immunoreactive fibers in the median eminence following different survival times, but also in their relation and apposition to vessels.

\section{Materials and Methods}

The experiments were carried out with the approval of Stockholms norra djurförsöksetiska nämnd, the local animal experimentation and ethics committee.

Surgical procedures. Male Sprague-Dawley rats (150-180 gm; ALAB, Stockholm, Sweden) were anesthetized with chloral hydrate $(350 \mathrm{mg}$ $\mathrm{kg}$ ), placed in a stereotaxic instrument, and hypophysectomized by aspiration through an intra-auricular approach (see Waynforth, 1980). The animals were allowed to survive for different periods $(5,14,30 \mathrm{~d}$; $2,3,9$, and 16 months), during which they were maintained with food and $5 \%$ glucose in a $0.9 \% \mathrm{NaCl}$ solution to drink ad libitum. Once the survival period was completed, the animals were sacrificed and processed for immunohistochemistry. A parallel group of animals with all the surgical procedures performed, but without the aspiration, as well as normal animals were added as controls.

Immunohistochemical procedure. Lesioned animals and controls were reanesthetized with sodium pentobarbital (Mebumal; $60 \mathrm{mg} / \mathrm{kg}$, i.p.) and perfused via the ascending aorta with $50 \mathrm{ml}$ of $\mathrm{Ca}^{2+}$-free Tyrode's solution $\left(37^{\circ} \mathrm{C}\right)$ followed by $50 \mathrm{ml}\left(37^{\circ} \mathrm{C}\right)$ of a mixture of $4 \%$ paraformaldehyde and $0.4 \%$ picric acid in $0.16 \mathrm{M}$ phosphate buffer at $\mathrm{pH} 6.9$ (Zamboni and de Martino, 1967), followed by ice-cold fixative (as above) for $6 \mathrm{~min}$. The brains were dissected out, and the completeness of the hypophysectomy was confirmed. The tissue was then immersed for 90 $\mathrm{min}$ in the same fixative and rinsed for at least $48 \mathrm{hr}$ in $0.1 \mathrm{M}$ phosphate buffer (pH 7.0) containing 10\% sucrose, $0.02 \%$ Bacitracin (Sigma, St. Louis, MO), and $0.01 \%$ sodium azide (Merck, Darmstadt, Germany). Cryostat sections (14 $\mu \mathrm{m}$ thick) of the hypothalamic region containing the median eminence were processed for the indirect immunofluorescence technique of Coons and collaborators (see Coons, 1958). Briefly, sections were mounted on precoated glass slides and incubated in a humid chamber with guinea pig antiserum to VP (1:2000; Elde and Hökfelt, 1978), rabbit antiserum to OXY (1:400; Morris, unpublished observation), GAL (1:400; RAS 7153, Peninsula Labs, Belmont, CA), DYN 1-17 (1:400; Vincent et al., 1980), VIP (1:800; Fahrenkrug et al., 1977, 1978), and PHI (1:800; Fahrenkrug and Pedersen, 1984), and mouse monoclonal antibodies to CCK-8 (1:400; Mab 2D4 and 28.2; Walsh, unpublished observation). The sections were thereafter rinsed in phosphate-buffered saline (PBS) and incubated for $30 \mathrm{~min}$ at $37^{\circ} \mathrm{C}$ with fluorescein isothiocyanate (FITC)-conjugated goat anti-rabbit (OXY, GAL, DYN, VIP, PHI) or goat anti-mouse (CCK, OXY-NP) antibodies (1:80; Boehringer-Mannheim Scandinavia, Stockholm, Sweden) or tetramethylrhodamine isothiocyanate isomer R (TRITC)-conjugated goat anti-guinea pig (VP) antibodies (1:20; Cappel, West Chester, PA). Finally, the sections were washed in PBS and coverslipped using PBS: glycerol (1:3) containing $0.1 \% p$ - phenylenediamine (Johnson and Nogueira Araujo, 1981; Platt and Michael, 1983) as mounting medium. In some cases, double-labeling experiments were performed incubating sections with a mixture of mouse monoclonal antibodies to tyrosine hydroxylase (TH; 1:400; Incstar, Stillwater, MN) and guinea pig antiserum to VP, or rabbit antiserum to growth hormone-releasing factor (GRF; 1:2000; Sawchenko et al., 1985) with mouse monoclonal antibodies to OXY-neurophysin (OXY-NP; Ben-Barak et al., 1984, 1985) and rabbit DYN antiserum with guinea pig VP antiserum. In these cases, a mixture of FITC-labeled goat anti-rabbit and TRITC-labeled goat anti-guinea pig antibodies (TH-VP and DYN-VP) or TRITC-labeled goat anti-rabbit (Boehringer-Mannheim Scandinavia) with FITClabeled sheep anti-mouse (1:10; Amersham, UK) antisera (GRF-OXY) were used. For control purposes, sections were also incubated with primary antibodies preabsorbed with their respective peptides $\left(10^{-6} \mathbf{M}\right)$.

The sections were examined in a Nikon Microphot-FX microscope equipped for epifluorescence and with filter cube B-2A for FITC-induced fluorescence $(450-490 \mathrm{~nm}$ exitation filter, $520-560 \mathrm{~nm}$ barrier filter, and a 520-550 extra barrier filter) or filter cube G-1B for TRITCinduced fluorescence $(546 / 10 \mathrm{~nm}$ excitation filter and $610 \mathrm{~nm}$ barrier filter). Kodak Tri-X black-and-white film was used for photography.

\section{Results}

\section{Vasopressin}

In normal animals, fibers exhibiting VP-LI could be seen arising from cell bodies in the PVN and SON running laterally toward the median eminence, where they merged to occupy the internal layer (Fig. 1A). Several VP-IR fibers could also be identified in the external layer in close relation to portal vessels. Five days 

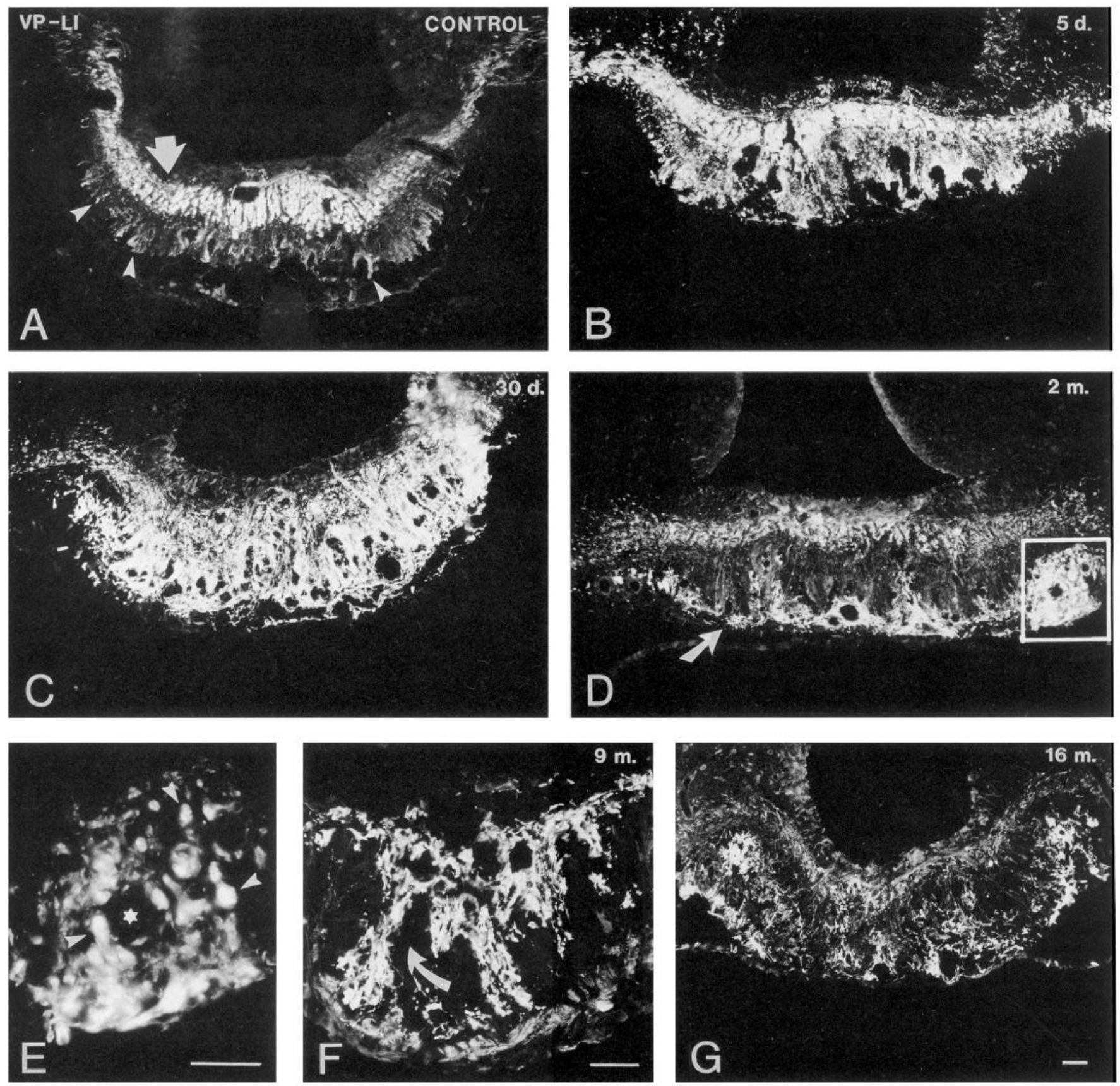

Figure 1. Immunofluorescence photomicrographs of sections of the median eminence from a control rat $(A)$ and hypophysectomized rats after 5 $\mathrm{d}(B), 30 \mathrm{~d}(C), 2$ months $(D), 9$ months $(F)$, and 16 months $(G)$ of survival, stained with antiserum to vasopressin (VP). In the median eminence of a control rat $(A)$ the distribution of the hypothalamo-neurohypophyseal tract within the internal layer (arrow in $A$ ) with a few immunostained fibers in the external layer (arrowheads) is shown. After hypophysectomy, there is a marked increase in the number of VP-IR fibers in the external layer $(B-G)$. In $D$, the arrow points to labeling in the external layer. Boxed area in $D$ is shown at a higher magnification in $E$, where a vessel (asterisk) is surrounded by several terminal-like swellings (arrowheads). Dense aggregations of VP-IR fibers surrounding portal vessels (curved arrow) are observed in $F$. Scale bars: $A-D$ and $G, 50 \mu \mathrm{m} ; E$ and $F, 100 \mu \mathrm{m}$.

after hypophysectomy, a marked change in VP-LI was observed within the median eminence. The intensity of the immunoreaction increased in the internal layer, and there was an increase in the number of immunoreactive fibers in the external layer (Fig. 1B). After longer survival times, the immunoreactivity progressively decreased in the internal layer, and after $30 \mathrm{~d}$ of survival, strongly VP-IR fibers were predominant in the external layer. An increased number of pericapillary VP-IR terminals forming a dense network surrounding portal vessels was identified (Fig. $1 C$ ). With longer survival times (2, 9, and 16 months), the rearrangement of fibers appeared to stabilize, and two groups of immunoreactive fibers were identified, one in the ventral part of the internal layer and another one in the external layer (Fig. $1 D$ ). Numerous fibers were also seen running between both 

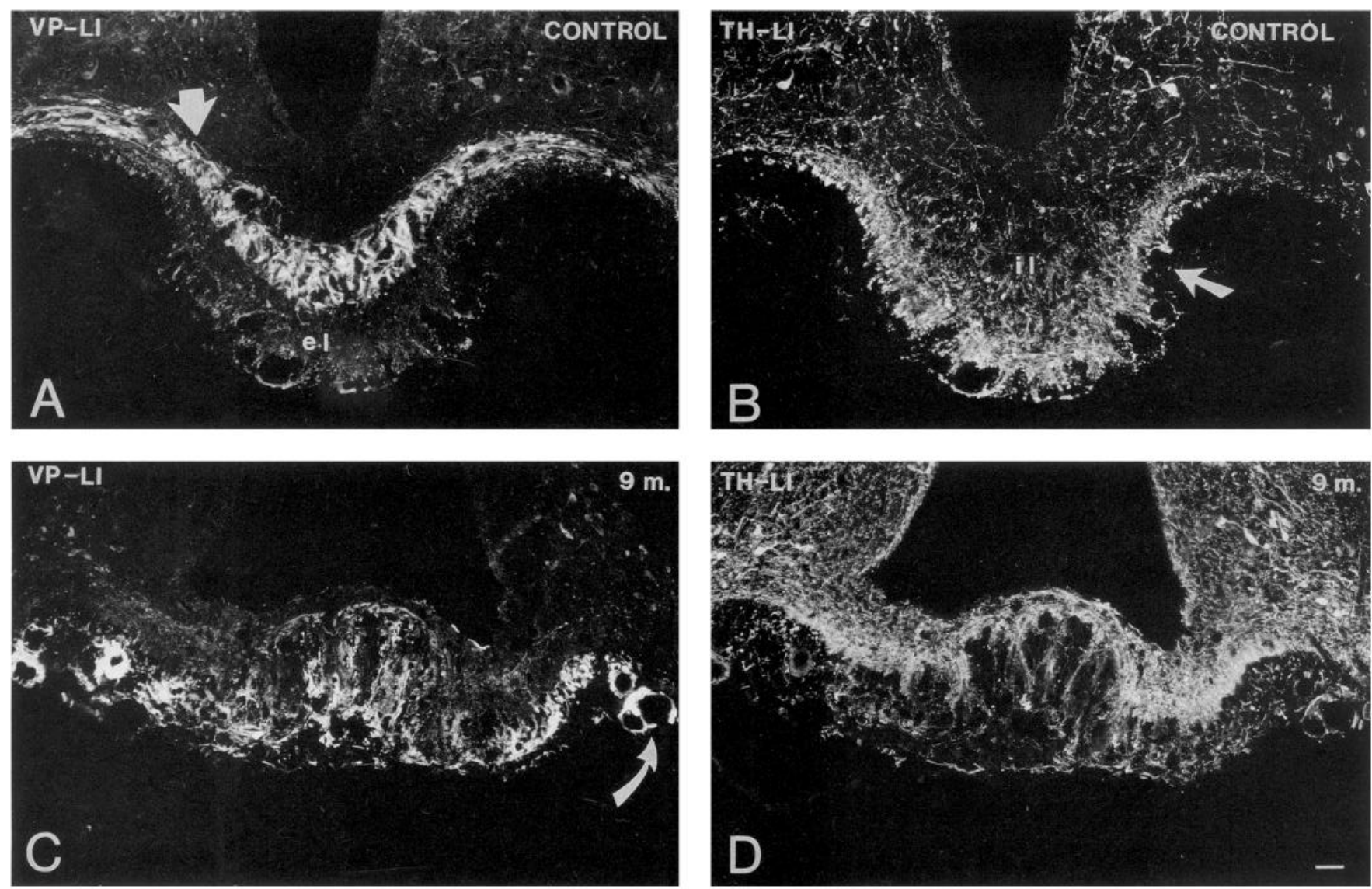

Figure 2. Immunofluorescence photomicrographs of sections of the median eminence from a control $(A, B)$ and a hypophysectomized rat after 9 months of survival $(C, D)$ double stained with antiserum to vasopressin $(V P ; A, C)$ and tyrosine hydroxylase $(T H ; B, D)$. Note the distribution of VP- and TH-LI, respectively, within the internal (arrow in $A$ ) and external (arrow in $B$ ) layers. After the lesion, VP-LI is observed mainly the superficial part of the external layer, whereas TH-LI is present in the inner parts of the median eminence. Curved arrow in $C$ points to a large vessel surrounded by a dense VP-IR plexus. $e l$, external layer; $i l$, internal layer. Scale bar, $50 \mu \mathrm{m}$.

layers (Fig. $1 D-G$ ). In addition, an increase in the number of immunoreactive fibers surrounding the lateral large vessels flanking the median eminence was observed (see Fig. 2C).

Double-labeling experiments combining VP and TH antisera were performed in order to assess a possible rearrangement of fibers within the median eminence. In normal animals, these experiments showed a complementary distribution of VP-/and TH-LI in, respectively, the internal and the external layers of the median eminence (Fig. 2A,B). However, 9 months after hypophysectomy, TH-LI was observed in fibers of the internal layer, whereas VP-IR fibers were present in the external layer of the median eminence (Fig. $2 C, D$ ).

\section{Oxytocin}

In general, OXY-IR fibers were in normal animals seen in the internal layer of the median eminence, whereas the external layer was devoid of this immunoreactivity (Fig. 3A). However, occasionally, single large OXY-IR fibers were seen in the lateral zone of the external layer (Fig. $3 A$ ). In $5 \mathrm{~d}$ hypophysectomized animals, a notable increase in the number of OXY-IR fibers was detected in the external layer, with a parallel decrease in the intensity of the immunoreaction in the internal layer (Fig. $3 B$ ). After $30 \mathrm{~d}$, and also at longer survival times, the number and intensity of OXY-IR fibers further increased within the external layer (Fig. $3 C-F$ ). Superficial vessels in the median eminence as well as the portal loops were completely surrounded by numerous terminal-like OXY-IR swellings (Fig. $3 E-G$ ). Strongly OXY-IR fibers and terminal-like structures surrounded the large vessels lateral to the median eminence (Fig. $3 F, G$ ). From 2 months onward, OXY-IR fibers were organized in one internal and one external layer (Fig. $3 D, H$ ).

Double-staining experiments in normal animals confirmed the distribution of OXY-LI in the internal layer, whereas GRFLI was present exclusively in the external layer of the median eminence (Fig. 4A,B). After 16 months of hypophysectomy, GRF-LI was mainly detected within the subependymal and internal layers, with very few GRF-IR fibers in the external layer, which in turn was occupied by OXY-IR (Fig. 4C,D).

\section{Galanin}

In normal animals, GAL-IR fibers were present in the external layer of the median eminence, with low numbers in the internal layer (Fig. 5A). After hypophysectomy, GAL-LI increased in the internal layer and already after $5 \mathrm{~d}$ a plexus of GAL-IR fibers was observed throughout the entire midportion of the median eminence including the subependymal layer (Fig. $5 B$ ). Subsequently, a progressive decrease in GAL-LI was detected at 14 $\mathrm{d}$, and by $30 \mathrm{~d}$ of survival very few immunoreactive fibers were present within the median eminence (Fig. $5 C, D$ ). However, with longer survival times, GAL-LI started to increase, and in 9 

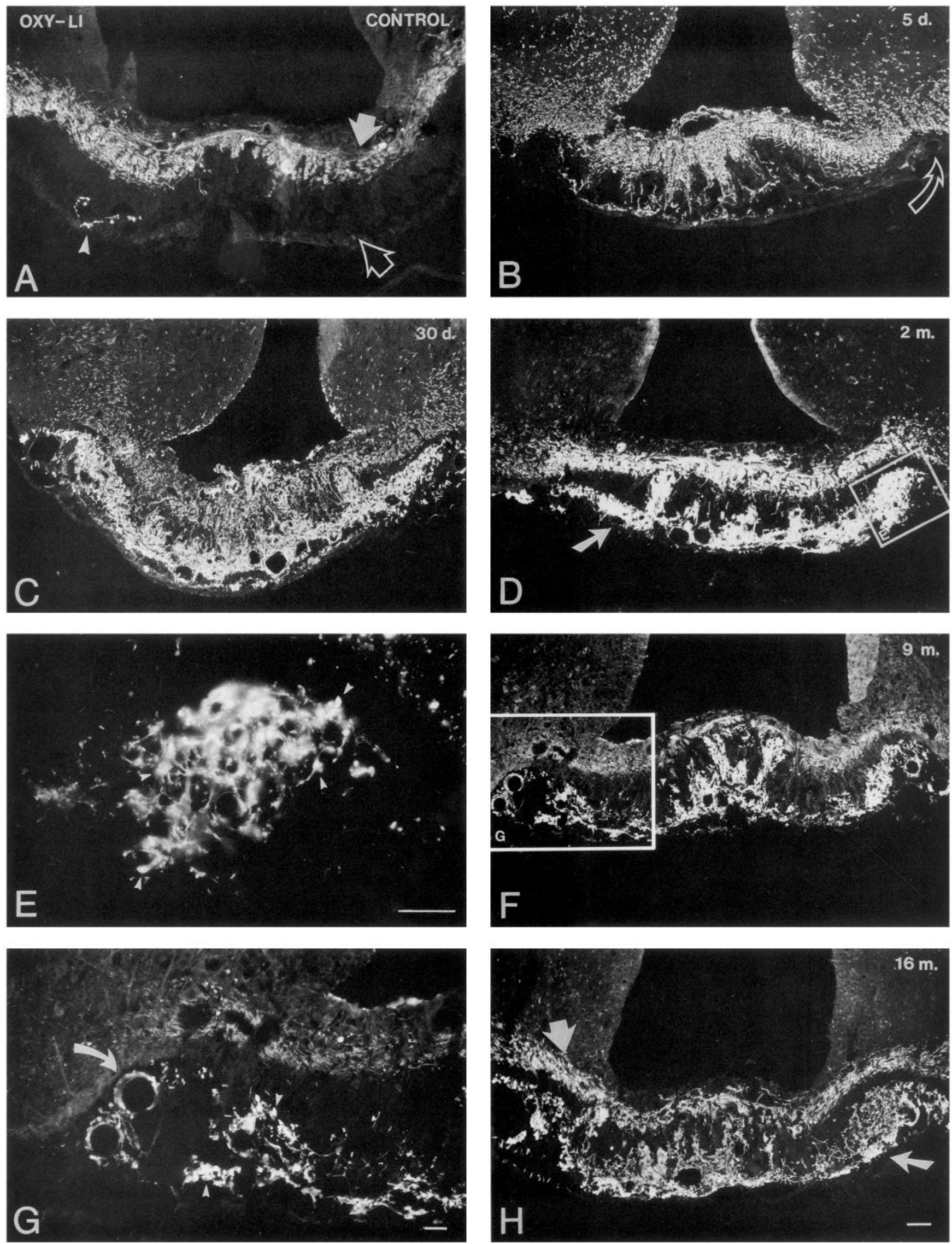

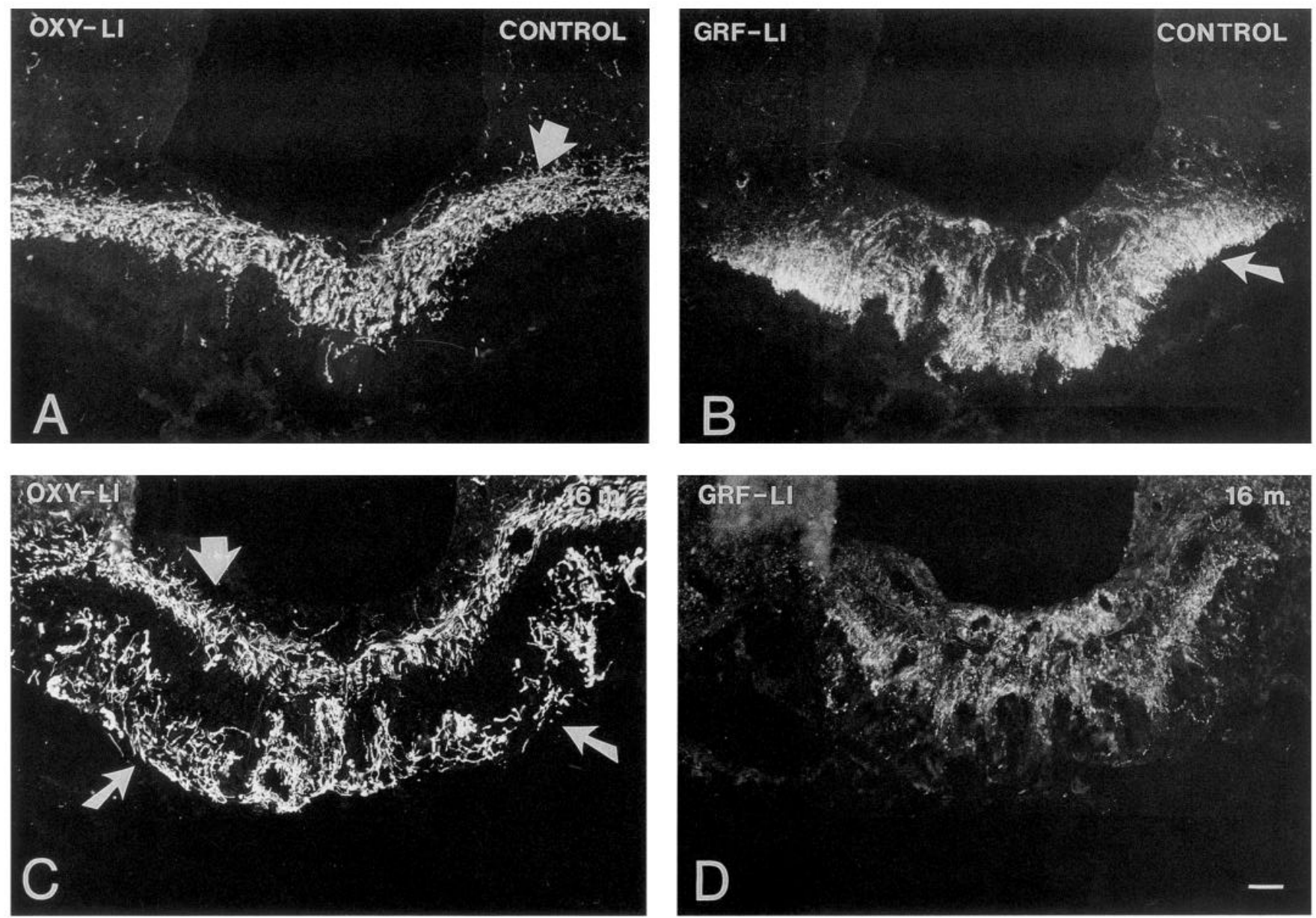

Figure 4. Immunofluorescence photomicrographs of sections of the median eminence from control $(A, B)$ and a hypophysectomized rats after 16 months of survival $(C, D)$ double-stained with antiserum to oxytocin $(O X Y)(A, C)$ and growth hormone-releasing factor $(G R F)(B, D)$. Note the distribution of OXY- and GRF-LI within, respectively, the internal (arrow in $A$ ) and external (arrow in $B$ ) layers. After the lesion, OXY-LI $(C$ ) adopts a double-layered distribution, with fibers in both the internal (thick arrow) and external (thin arrows) layers, whereas GRF-LI is present mainly in the internal layer of the median eminence $(D)$. Scale bar, $50 \mu \mathrm{m}$.

months postlesion animals, a strong immunoreactivity was observed mainly in the internal layer (Fig. $5 E$ ). Here, the fibers and terminal-like structures surrounded some vessels, and some GAL-IR fibers had a dorsoventral/ventrodorsal orientation (Fig. $5 E, G)$. Also, the lateral large vessels were innervated by GALIR fibers (Fig. $5 F, G$ ). Finally, 16 months after the hypophysectomy, GAL-LI was very intense and present in all subdivisions of the median eminence, including the subependymal layer (Fig. $5 F)$.

\section{Cholecystokinin}

In normal animals, CCK-LI was mainly confined to the external layer of the median eminence, although frequently strongly im- munoreactive networks of fibers and terminals surrounded vessels in the internal layer (Fig. 6A). During short survival times, changes in CCK-LI paralleled those in GAL-LI. At $5 \mathrm{~d}$, the number of CCK-IR fibers in the external layer was decreased, and a dense plexus of CCK-IR fibers was observed in the internal layer (Fig. 6B). However, 14 and also $30 \mathrm{~d}$ postlesion, the immunoreactivity decreased in the internal layer, and only a few CCK-IR fibers were present in the external layer (Fig. 6C,D). Thereafter, swollen, strongly immunostained terminals could be observed surrounding all types of vessels, and a network of immunostained fibers of varying thickness was also noticed in the external layer and in the midline area of the internal layer (Fig. $6 E, F$ ). In double-labeling experiments, CCK-LI was de-

Figure 3. Immunofluorescence photomicrographs of sections of the median eminence from a control $(A)$ and hypophysectomized rats after $5 \mathrm{~d}$ $(B), 30 \mathrm{~d}(C), 2$ months $(D), 9$ months $(F)$, and 16 months $(H)$ of survival, stained with antiserum to oxytocin $(O X Y)$. Note the prominent distribution of OXY-LI within the internal layer of the median eminence (solid arrow) in the normal rat $(A)$ and the lack of immunoreactivity in the external layer (open arrow) with the exception of only a few immunostained fibers (arrowhead). Curved arrow in $B$ points to the lateral large vessels devoid of immunostained innervation. After 2 months, a very strong plexus of immunoreactive fibers is observed within the external layer (arrow in D). Boxed areas in $D$ and $F$ are shown at higher magnifications in $E$ and $G$, respectively. Arrowheads in $E$ point to strongly immunoreactive terminal-like swellings. At 9 months $(G)$, the lateral large vessels are surrounded by OXY-IR fibers (curved arrow). Note the double-layered distribution of OXY-LI within the internal (thick arrow) and the external layers (thin arrow) of the median eminence after 16 months of survival $(H)$. Scale bars: $A-D$, and $F$ and $H, 50 \mu \mathrm{m} ; E$ and $G, 25 \mu \mathrm{m}$. 

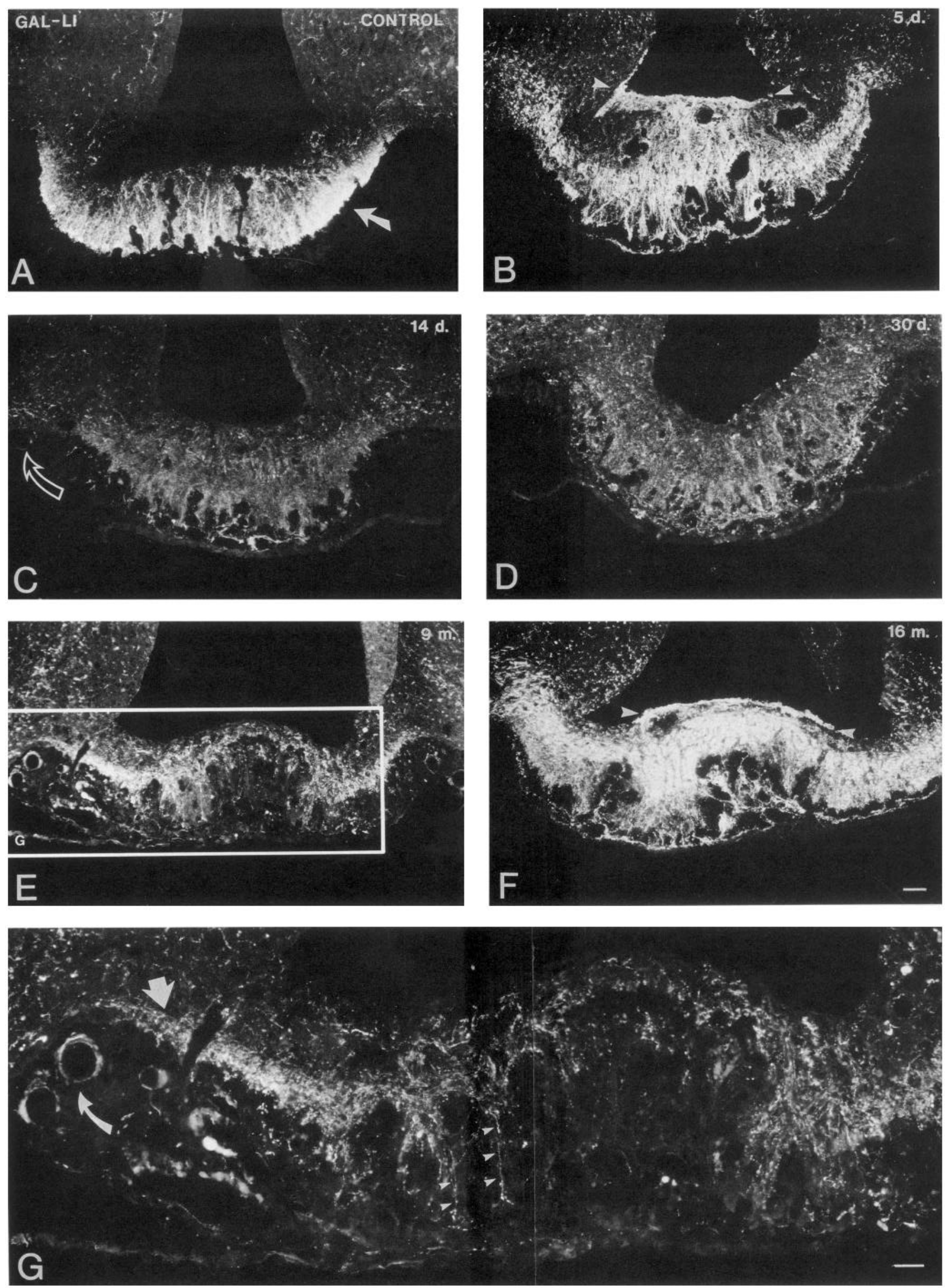
tccted only in a population of the OXY-IR fibers in the external layer of the median eminence and not in those of the internal layer (Fig. 6G,H).

\section{Dynorphin}

In normal animals, DYN-LI could be seen only in a few fibers in the lateral aspects of the median eminence, and single immunopositive fibers were detected in the internal and external layers (Fig. $7 A$ ). However, $5 \mathrm{~d}$ after hypophysectomy there was a dramatic increase in DYN-LI at all levels of the median eminence including the subependymal layer (Fig. $7 \mathrm{~B}$ ). Later on, there was a slow and progressive decrease in the immunoreactivity, and both in 9 and 16 months postlesioned animals, strongly immunopositive fibers and terminals surrounded vessels in the external layer often in a patchy fashion (Fig. $7 C-F$ ). The large, lateral vessels were also strongly innervated.

Double labeling showed presence of DYN-LI in most VP-IR fibers (Fig. 7C,E). The lateral large superficial vessels were densely innervated by fibers containing both VP- and DYN-LI (Fig. $7 C, E)$.

\section{Vasoactive intestinal polypeptide/peptide histidine-isoleucine}

In general, VIP and PHI antisera labeled the same type of structures in the median eminence, and therefore we refer to them as VIP/PHI-IR,-positive, or to VIP/PHI-LI.

Normal animals showed almost no VIP/PHI-IR fibers within the median eminence. However, strong VIP/PHI-IR bundles of fibers were observed around lateral blood vessels and around superficial portal vessels on the ventral surface of the median eminence (Fig. $8 A, B$ ). At $5 \mathrm{~d}$ after hypophysectomy, a sparse network of immunopositive fibers was observed in the internal layer extending into the external layer (Fig. 8C). At 9 months postlesion, numerous fibers containing VIP/PHI-LI were present in both the internal and external layers (Fig. $8 D$ ), and after 16 months, a dense innervation of strongly immunofluorescent fibers and terminals surrounded numerous portal (Fig. $8 E-H$ ). However, VIP/PHI-LI was not observed around the large lateral and superficial vessels, as seen in control rats.

\section{Controls}

None of the immunoreactivities described above were observed after preincubation of the different antisera with their respective peptides.

\section{Discussion}

The present results show dramatic changes in the expression of several peptides within neurosecretory fibers in the median eminence after hypophysectomy. It is at present difficult to understand the mechanisms underlying these changes - they could be due to alterations in release and/or in synthesis. Some patterns are multiphasic, for example, for GAL- and CCK-LI, which increase initially, then drop, and finally become very high again. Some insight may be gained from comparison with an earlier report on mRNA levels in PVN and SON after hypophysectomy, but the longest postlesion time analyzed in that study was $36 \mathrm{~d}$ (Villar et al., 1990). Furthermore, the present study shows that injured neurosecretory fibers undergo a pronounced reorganization within the median eminence, in particular, in their relation to vessels. It is striking that several of these changes are long lasting and are still present after survival times longer than 1 year.

\section{Vasopressin and oxytocin expression}

The changes observed in the expression of VP- and OXY-LI after hypophysectomy are in agreement with those taking place in the soma of magnocellular PVN and SON neurons (Meister et al., 1990; Villar et al., 1990). Thus, VP mRNA levels in cell bodies are elevated (Villar et al., 1990), and the number of VPIR fibers exhibit a notable increase in the internal layer of the median eminence at early survival times after hypophysectomy. In contrast, OXY mRNA levels and the number of OXY-IR fibers decrease. Therefore, the possibility is raised not only that the lesion produces an accumulation of VP at the end of transected fibers, but also that the increase is the result of newly synthesized peptide. Conversely, the decrease observed for OXY$\mathrm{LI}$ in the internal layer could be due to release of the peptide, but also to a reduction in synthesis. Nevertheless, at longer survivals VP-LI and OXY-LI had similar distribution patterns and intensities of immunostaining. The appearance of immunopositive fibers between the internal and external layers early after the lesion, and the subsequent progressive increase in VPand OXY-LI in the external layer suggest that injured neurosecretory fibers present in the internal layer start a regrowing process in search for vessels within the median eminence. In fact, the double labeling with VP and TH antisera (Fig. 2), as well as with OXY and GRF antisera (Fig. 4), suggests that regenerating neurosecretory fibers from the internal layer grow into the external layer and "displace" originally superficially located fibers. Thus, the picture appears as an inversion of the layered organization of the median eminence. This should be further investigated, for example, by tracing experiments, to determine the origin of fibers within the median eminence of long-term hypophysectomized animals.

\section{Galanin and cholecystokinin expression}

In the median eminence of normal animals both GAL- and CCK-LI are mainly present within fibers in the external layer (Ch'ng et al., 1985; Kiss, 1985; Skofitsch and Jacobowitz, 1985; Melander et al., 1986a,b), and very little, if any, GAL- and CCKLI are expressed in normal fiber systems originating in magnocellular neurons of the PVN and SON nuclei. Hypophysectomy induced dramatic changes in the distribution of GAL- as well as of CCK-LI, with prominent increases in the internal

\footnotetext{
Figure 5. Immunofluorescence photomicrographs of sections of the median eminence from a control $(A)$ and hypophysectomized rats after $5 \mathrm{~d}$ $(B), 14 \mathrm{~d}(C), 30 \mathrm{~d}(D), 9$ months $(E, G)$ and 16 months $(F)$ of survival stained with antiserum to galanin $(G A L)$. Boxed area in $E$ is shown at higher magnification in $G$. $A$, GAL-LI is normally present mainly in the external layer of the median eminence (arrow). Lateral large vessels are normally, as well as after short survival times postlesion, devoid of GAL-IR fibers (curved arrow in $C$ ). However, with a longer survival (see $G$ ), these vessels acquire a dense innervation of GAL-IR (curved arrow in $G$ ). A dense plexus of GAL-IR fibers (arrowheads) is seen in the subependymal zone both at $5 \mathrm{~d}(B)$ and 16 months $(F)$ after hypophysectomy. Also note the presence of bundles of GAL-IR fibers in the internal layer $(t h i c k$ arrow in $G$ ), with some fibers (small arrowheads) running in between the internal and external layers of the median eminence. Scale bars: $A-F$, 50 $\mu \mathrm{m} ; G, 25 \mu \mathrm{m}$.
} 

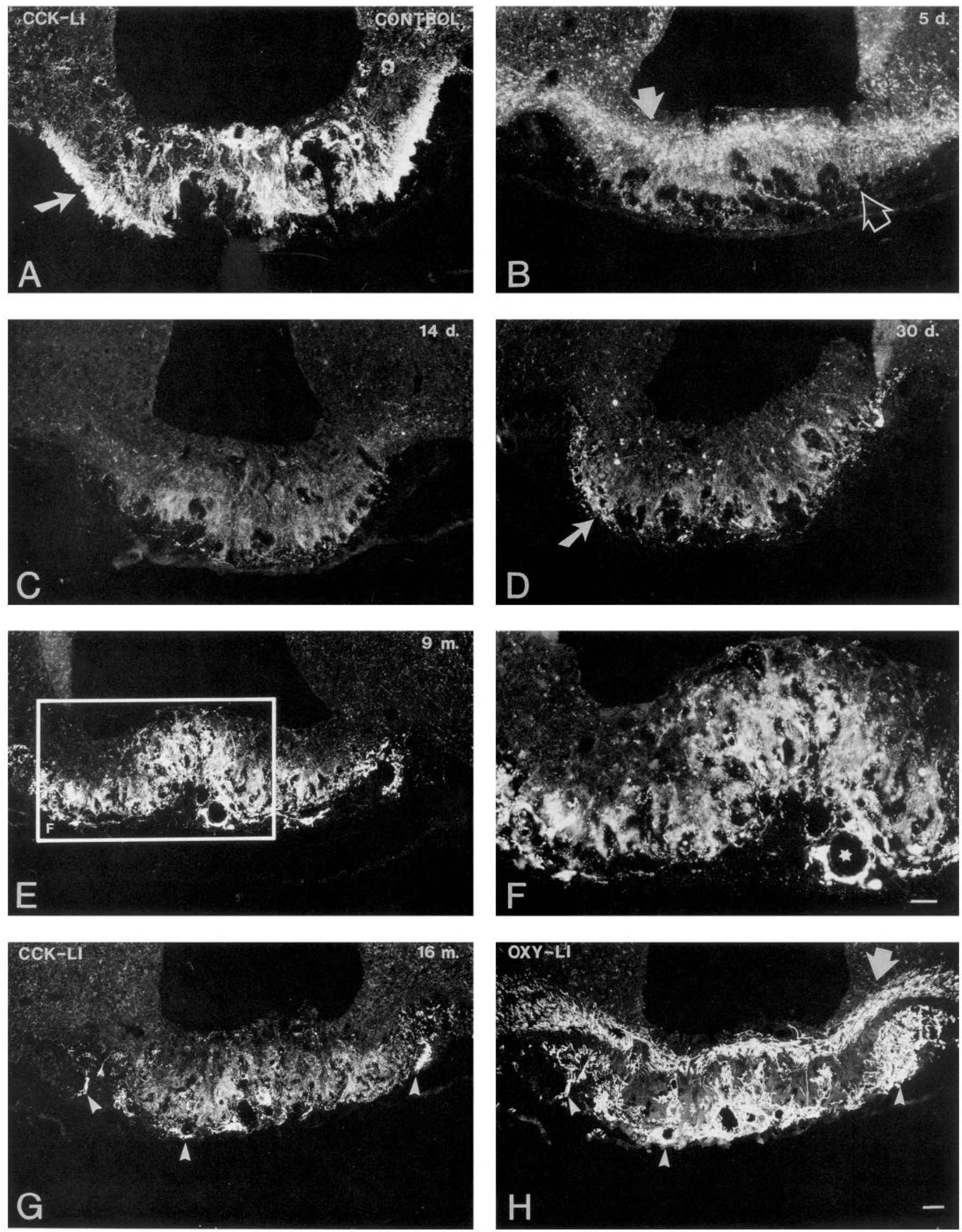

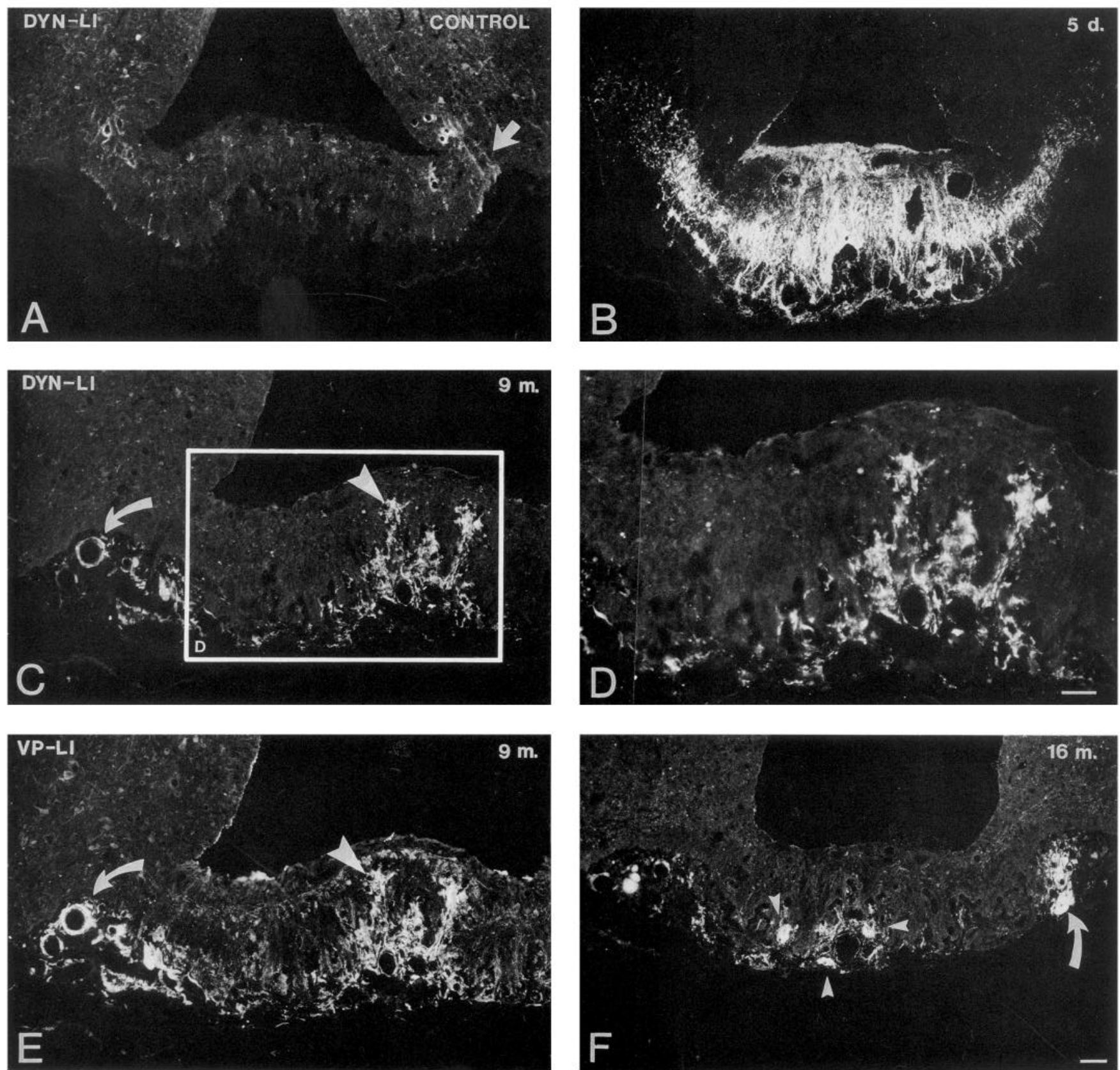

Figure 7. Immunofluorescence photomicrographs of sections of the median eminence from a control $(A)$ and hypophysectomized rats after $5 \mathrm{~d}$ $(B), 9$ months $(C-E)$, and 16 months $(H)$ of survival stained with antiserum to dynorphin $(D Y N ; A-D, F)$ and vasopressin $(V P ; E)$. In the control rat, DYN-LI is observed in the lateral aspects of the median eminence (arrow in A). Boxed area in $C$ is shown at higher magnification in $D$. C and $E$ show the same section double labeled with DYN and VP antisera, where the large vessels in the ventrolateral part of the median eminence (curved arrows) are surrounded by VP-IR fibers partly colocalizing DYN-LI. Large arrowheads point to double-stained fibers within the median eminence. After 16 months, a patchy distribution of DYN-LI is detected in the external layer (small arrowheads) often surrounding vessels (curved arrow, $F$ ). Scale bars: $A-C, E$, and $F, 50 \mu \mathrm{m} ; D, 25 \mu \mathrm{m}$.

Figure 6. Immunofluorescence photomicrographs of sections of the median eminence from control $(A)$ and hypophysectomized rats after $5 \mathrm{~d}(B)$, $14 \mathrm{~d}(C), 30 \mathrm{~d}(D), 9$ months $(E, F)$ and 16 months $(G, H)$ of survival, stained with antiserum to cholecystokinin $(C C K ; A-G)$ and oxytocin $(O X Y$; $H$ ). The normal distribution of CCK-LI $(A)$ is predominant in the external layer of the median eminence (arrow). However, after the lesion there is a decrease of immunoreactivity in the external layer (open arrow in B) and an increase in the hypothalamo-neurohypophyseal bundle present within the internal layer (solid arrow). Note the decrease in CCK-LI at 14 and $30 \mathrm{~d}$ of survival, with only a few immunostained fibers in the external layer (arrow in D). Boxed area in $E$ is shown at higher magnification in $F$, where a vessel (asterisk) is shown surrounded by a strongly CCK-IR network of fibers and terminal-like swellings. $G$ and $H$ show a double-stained section, where fibers colocalizing CCK-LI and OXY-LI are observed within the external layer (see arrowheads), whereas OXY-positive fibers within the internal layer (thick arrow in $H$ ) do not exhibit CCK-LI. Scale bars: $A-E, G$, and $H, 50 \mu \mathrm{m} ; F, 25 \mu \mathrm{m}$. 

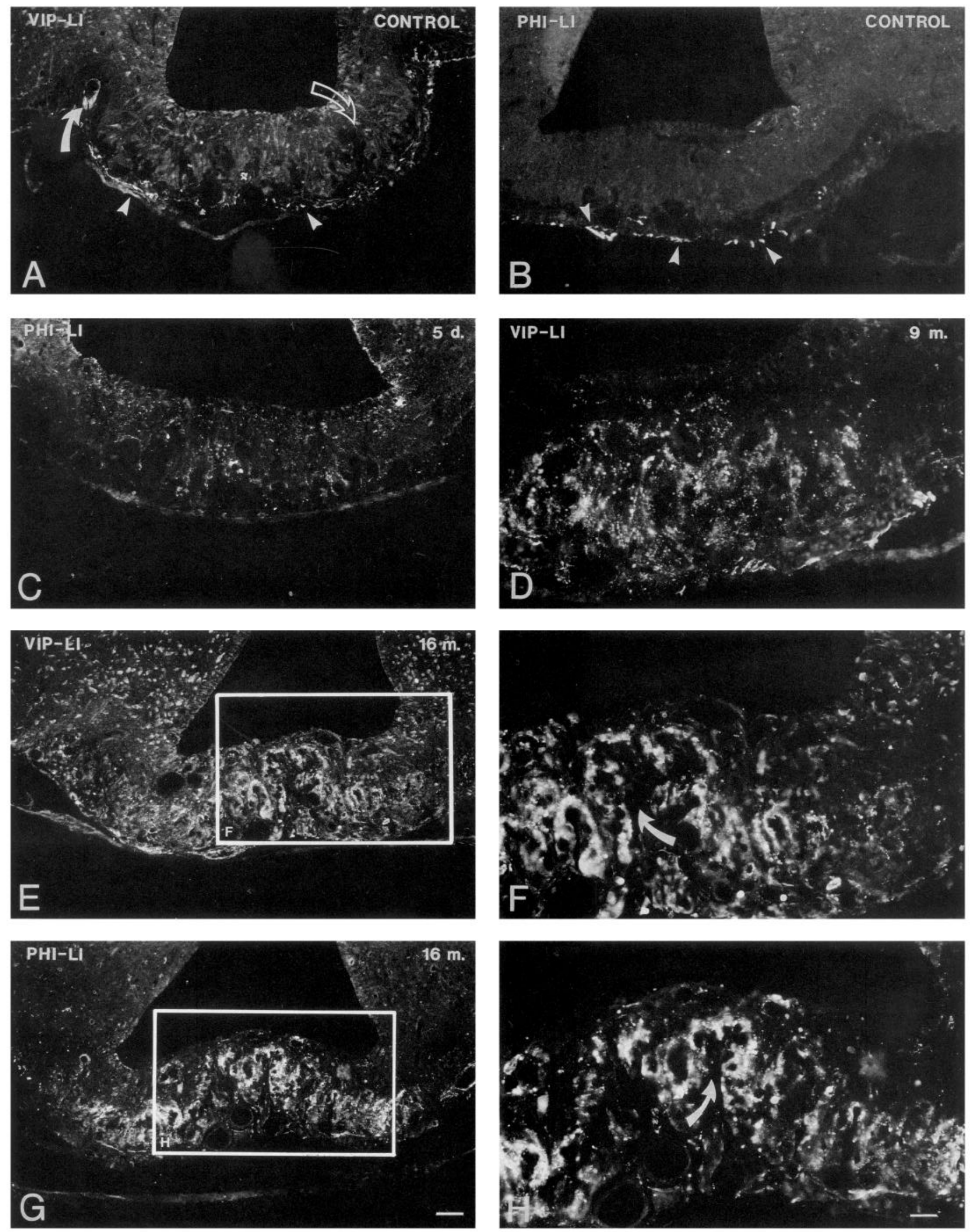
layer. Interestingly, a peak of intense expression of GAL-LI within fibers in the midline area of the internal layer was observed at $5 \mathrm{~d}$ of survival, coinciding with the peak values for GAL mRNA in magnocellular somata (Villar et al., 1990). Also, CCK-LI increased in the internal layer at early survival times as did the CCK mRNA in the magnocellular neurons, although not as dramatically as seen for G $\Lambda \mathrm{L}-\mathrm{LI}$ and $\mathrm{G} \Lambda \mathrm{L}$ mRN $\Lambda$. In addition, CCK-LI was reduced in the external layer, suggesting an indirect effect of the lesion on parvocellular CCK-containing neurons. Previous studies have, in fact, shown a parallel increase in CCK mRNA in parvocellular neurons after hypophysectomy (Villar et al., 1990). The intensity of both GAL- and CCK-LI was decreased at $14 \mathrm{~d}$ of survival and was markedly reduced after $30 \mathrm{~d}$, again paralleling mRNA levels. Thus, with regard to the internal layer the initial transient changes in GAL and CCK may reflect changes in synthesis. Subsequently, both GAL- and CCK-LI progressively increased, especially GAL with strongly immunostained fibers at all levels of the median eminence including the subependymal zone.

GAL-LI is mainly colocalized in magnocellular VP-IR neurons (Brownstein and Mezey, 1986; Melander et al., 1986b; Rökaeus et al., 1988; Gaymann and Martin, 1989; Meister et al., 1990), whereas CCK-LI is mainly present in OXY-IR neurosecretory neurons (Vanderhaeghen et al., 1981; Martin et al., 1983; Meister et al., 1990). The fact that the double labeling with CCK and OXY antisera after long survivals only showed OXY/CCK-LI-containing fibers within the external layer of the median eminence indicates that CCK-LI is mainly present in newly regenerated magnocellular fibers. We did not perform double labeling with VP and GAL antisera, but the massive distribution of GAL-LI after long survivals suggests that it is present in most vasopressinergic fibers. However, at 16 months there were many more GAL-IR fibers that for any other peptide. Some of these fibers may also harbor "parvocellular" peptides from the arcuate nucleus, such as GRF (Meister and Hökfelt, 1988; Meister et al., 1989) and from the PVN. The strong staining in the subependymal zone, on the other hand, was unique for GAL, and the origin of these fibers is unknown. One should, however, mention that GAL is a peptide that has been shown to be upregulated in many neuronal systems after various experimental manipulations (see below).

\section{Dynorphin expression}

At short survival times DYN-LI showed the most dramatic increase of all peptides studied here. Being almost completely absent in normal animals, it was intensely present throughout the entire median eminence after $5 \mathrm{~d}$, with a distribution almost identical to that of GAL-LI (compare Figs. $5 B, 7 B$ ): Interestingly, our previous in situ hybridization study (Villar et al., 1990) showed a decrease in DYN mRNA in magnocellular neurons during this period. Hence, in this case, the increase in the immunostaining may be the result of an accumulation/inhibition of release of the peptide in lesioned neurosecretory fibers. In addition, fibers in the external layer presumably originating in parvocellular systems now seem to have upregulated DYN levels. The subsequent progressive marked decrease in the number of the immunostained fibers to a final stage, where a limited number of strongly immunoreactive fibers remained in the external layer, suggests that DYN is of particular importance immediately after the lesion. The double labeling performed on rats 9 months after hypophysectomy indicated that the majority of DYN-IR fibers at that time belong to the vasopressinergic population of neurosecretory fibers.

\section{Vasoactive intestinal polypeptide/peptide histidine-isoleucine expression}

VIP/PHI fibers in the median eminence have at least three different origins. One subpopulation corresponds to neurosecretory fibers from the magnocellular neurons, in which VIP mRNA increases after short-term hypophysectomy (Ceccatelli et al., 1991). There are also VIP/PHI-positive cells in the parvocellular part of the paraventricular nucleus that project to the median eminence (Hökfelt et al., 1987; Ceccatelli et al., 1991). Moreover, bundles of VIP/PHI-LI-containing fibers in the superficial part of the median eminence may have a peripheral origin (Ceccatelli et al., 1988, 1991). To what extent each of these populations contributes to the changes in expression reported here is not fully clear. However, the early changes observed as well as the increase in VIP mRNA (Ceccatelli et al., 1991 ) in magnocellular neurons indicate that some VIP/PHILI increase occurs in neurosecretory axons.

VIP- and PHI-LI have previously been shown to increase in the internal layer of the median eminence of hypophysectomized animals already after $24 \mathrm{hr}$ of survival, with a fairly dense network of fibers extending into the external layer at $48 \mathrm{hr}$ (Ceccatelli et al., 1991). After $5 \mathrm{~d}$, VIP/PHI-IR fibers were observed in contact with portal vessels, and from then on the innervation progressively increased. Finally, after the longer survivals studied, most vessels within the median eminence were surrounded by VIP/PHI-IR fibers. Interestingly, however, the dense VIP/ PHI innervation of the large, lateral vessels seen in control rats was not observed after long-term hypophysectomy. Instead, these vessels, as discussed above, were surrounded by a dense fiber network expressing other peptides. It may be speculated that VIP/PHI fibers are "pushed away" by regenerating fibers containing these other peptides.

\section{Functional aspects}

Since Stutinsky (1951), more than 40 years ago, described the generation of a new neural lobe at the end of transected neurosecretory fibers, numerous studies have been performed to study the series of processes occurring after such lesions. Most of these studies have focused on changes taking place in magnocellular neurons as well as on the regrowth of neurosecretory terminals and the reinnervation of fenestrated vessels at the level of the median eminence (Rasmussen, 1940; Frykman, 1942;

$\leftarrow$

Figure 8. Immunofluorescence photomicrographs of sections of the median eminence from a control rat $(A$ and $B)$ and hypophysectomized rats after $5 \mathrm{~d}(C)$ and 9 months $(D)$ and 16 months $(E-H)$ of survival stained with antiserum to vasoactive intestinal polypeptide $(V I P ; A, D, E, F)$ and peptide histidine-isoleucine $(P H I ; B, C, G, H)$. In control animals, VIP-LI $(A)$ and PHI-LI $(B)$ are observed in the most superficial parts of the median eminence (arrowheads). Some vessels in the lateral parts of the median eminence are also surrounded by immunoreactive fibers (solid curved arrow). No immunoreactivity is ohserved in relation to portal vessels (open curved arrow). However, after 16 months of hypophysectomy, strongly VIP-IR $(E, F)$ and PHI-IR $(G, H)$ fibers surround portal vessels (curved arrows in $F$ and $H$ ). Boxed areas in $E$ and $G$ are shown at higher magnifications, respectively, in $F$ and $H$. Scale bars: $A-C, E$, and $G, 50 \mu \mathrm{m} ; D, F$, and $H, 25 \mu \mathrm{m}$. 


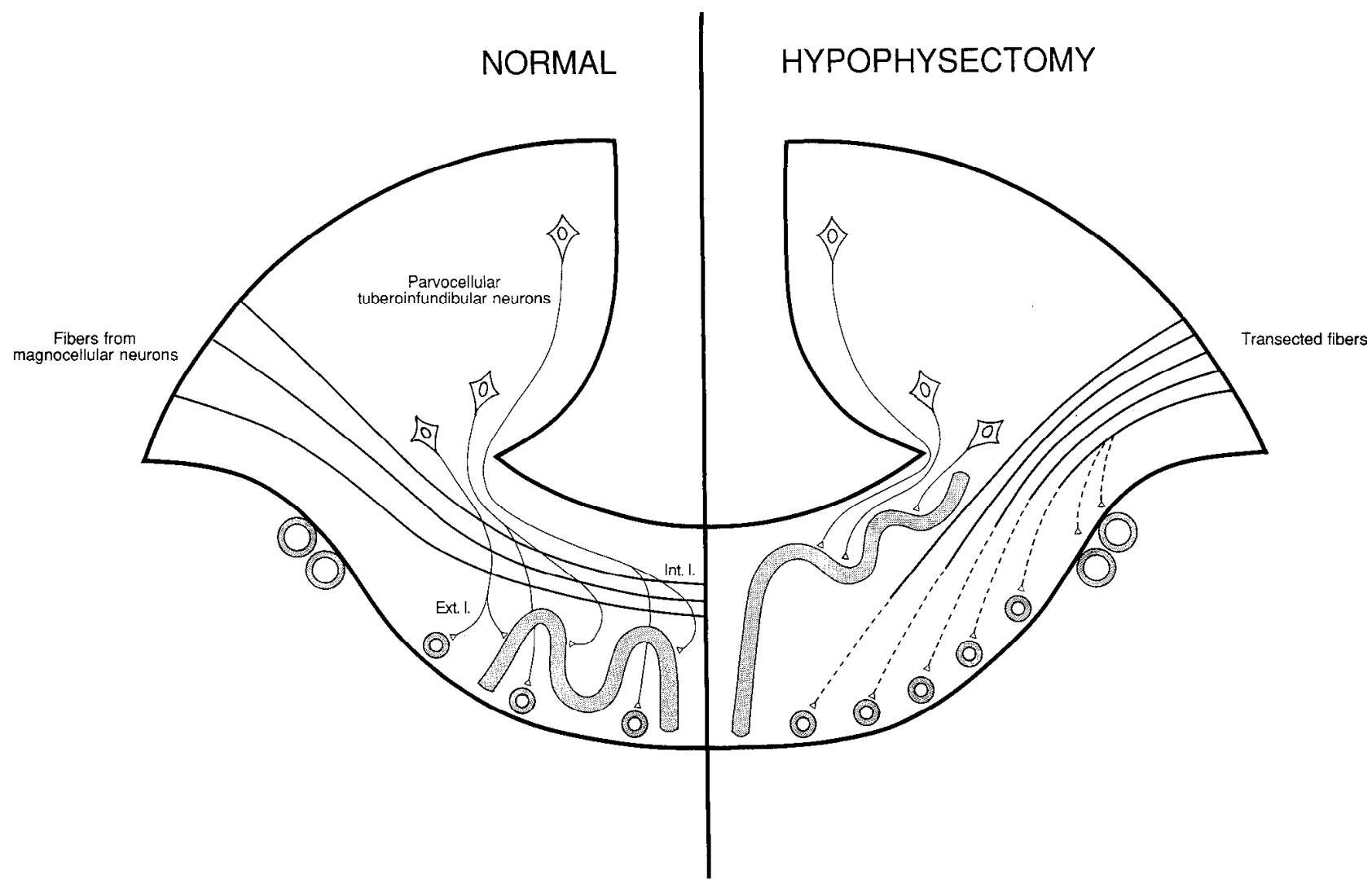

Figure 9. Schematic drawing showing the suggested reorganization of fibers within the median eminence after hypophysectomy. In control animals (left), fibers originating in magnocellular hypothalamic neurons occupy the internal layer, whereas those from parvocellular cells occupy the external layer. After hypophysectomy (right), surviving fibers from magnocellular cells regrow in search of vessels within the external layer. As a consequence, those terminals originally located within the external layer acquire a new location in the inner parts of the median eminence.

Bodian and Marsen, 1951; Moll and De Wied, 1962; Dellman, 1973; Raisman, 1973; Danilova and Polenov, 1977; Antunes et al., 1980; Burlet et al., 1983; Herman et al., 1986, 1987; Meister et al., 1990; Villar et al., 1990, 1991a, 1993; Ceccatelli et al., 1991). In addition, explants of neurohypophysis, sciatic nerve, or hypodermal connective tissue have been grafted close to the severed neurosecretory fibers in order to provide a network of capillaries to determine the role of these types of environments for regeneration (Dellman et al., 1987; Carithers and Dellman, 1992). These studies showed that regeneration seems to depend not only on the access of neurosecretory fibers to vessels, but also on the presence of pituicytes.

In gencral, the present findings show that many ncurosecretory transected fibers tend to regrow, presumably in search for vessels within the median eminence (Fig. 9), and suggest that this may be a process of importance for survival. In fact, it is tempting to propose that the chance of fibers to survive and subsequently form a new neural lobe depends on their reaching the portal vessels. Since neurosecretory neurons normally send their projections to vessels, where there is no blood-brain barrier, it is possible that they, apart from trophic factors provided by pituicytes and other elements (Dellman and Carithers, 1992), receive trophic influences from the blood in portal vessels and capillaries in the neural lobe.

An open question is if colocalized peptides play a role in the process of regeneration after injury. There are many examples of changes in peptide expression in several neural systems in response to lesions. For instance, primary sensory neurons increase GAL- and VIP/PHI-LI as well as their mRNAs after sciatic nerve lesion, while substance P- and calcitonin generelated peptide (CGRP)-LI are decreased (Jessell et al., 1979; Shehab and Atkinson, 1986; Villar et al., 1989, 1991b; Dumoulin et al., 1991). GAL- and CGRP-LI and their mRNAs are increased in motoneurons after the same type of lesions (Arvidsson et al., 1989a,b; Moore, 1989; Haas et al., 1990; Piehl et al., 1991; Saika et al., 1991; Zhang et al., 1993). Furthermore, dorsal raphe neurons increase their amounts of GAL-LI and its mRNA after decortication (Cortés et al., 1990b; see also Cortés et al., 1990a). Interestingly, some of these upregulated substances have becn shown to be transported out to the lesion site (Cortés et al., 1991; Villar et al., 1991c), as is also suggested by our present findings in neurosecretory transected fibers.

The fact that several of the peptides studied modify their expression in a long-lasting manner suggests that their physiological role is altered in lesioned neurons. For example, the wellknown vasodilatory effect of VIP (Said and Mutt, 1970) could support regeneration by increasing the blood flow. In addition, it has, in general terms, been proposed that compounds that are upregulated in neurons after lesions serve to promote survival and regeneration (Lieberman, 1971; Barron, 1983; Kreutzberg, 1992). It is also known that some peptides in fact have trophic actions (see Hökfelt, 1991; Strand et al., 1992). It is therefore possible that some of the peptides observed here to increase after axotomy in fact may play such a role. In relation to the 
CONTROL
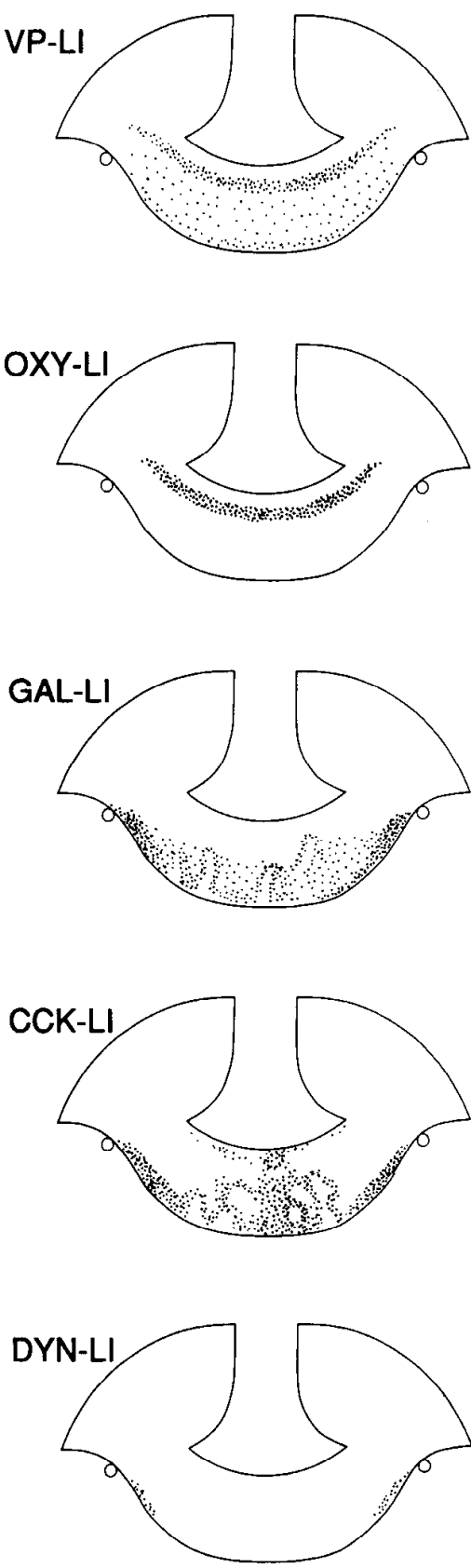

VIP/PHI-LI

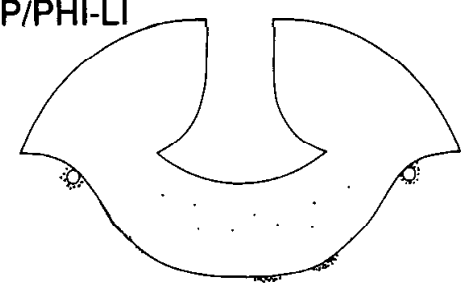

5 d. HPX
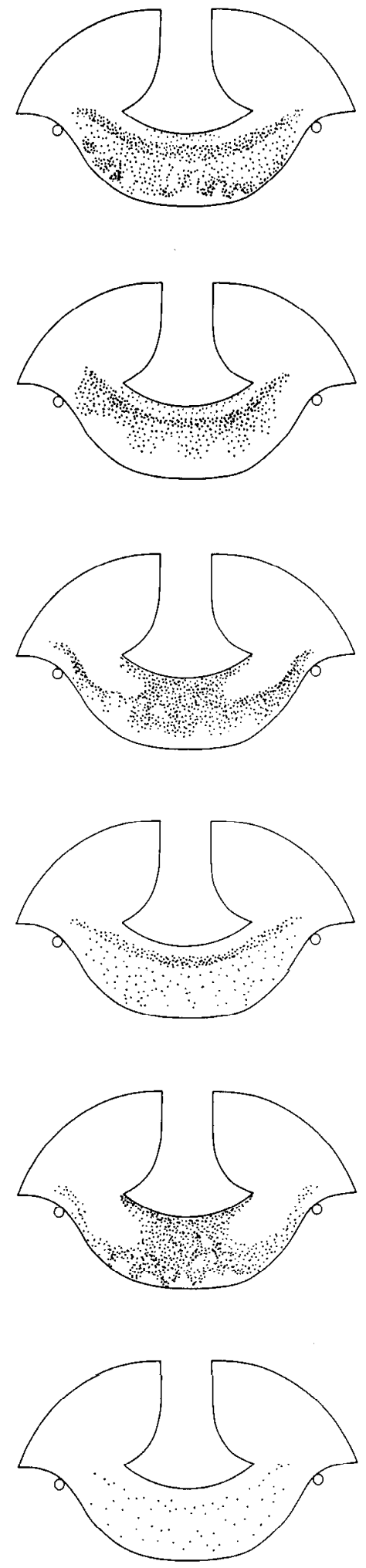

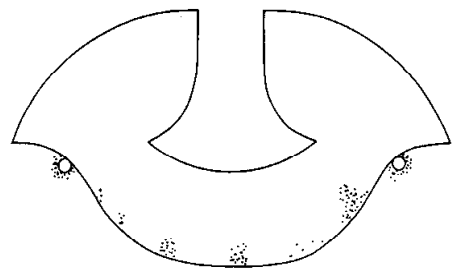

$16 \mathrm{~m} . \mathrm{HPX}$
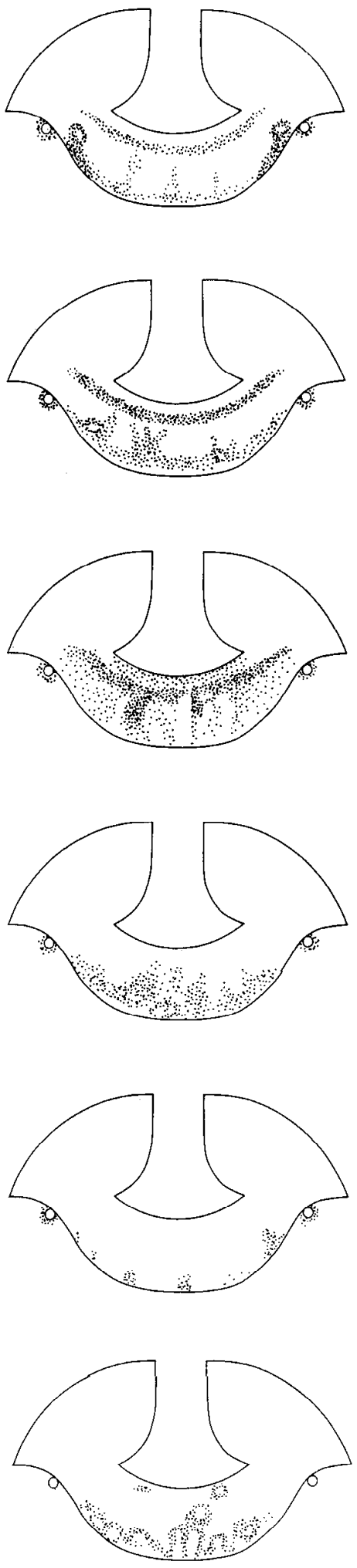

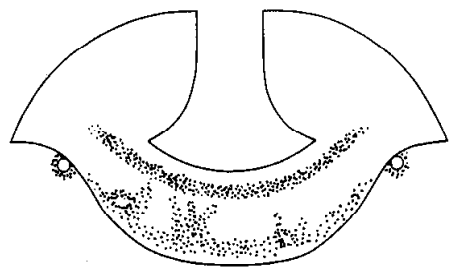

Figure 10. Schematic drawing summarizing the distribution and relative numbers of vasopressin $(V P)$-, oxytocin $(O X Y)$-, galanin $(G A L)$-, cholecystokinin $(C C K)$-, dynorphin $(D Y N)$-, and vasoactive intestinal polypeptide/peptide histidine-isoleucine (VIP/PHI)-LI fibers in the median eminence of control animals and $5 \mathrm{~d}$ and 16 months after hypophysectomy. 
present findings, VIP has been shown to promote neuronal survival in cell culture (Brenneman and Eiden, 1986; Pincus et al., 1990), to stimulate the growth of human keratocytes (Haegerstrand et al., 1989), and more recently to stimulate embryo growth (Gressens et al., 1993). A recent study has also discussed trophic actions of GAL on pituitary lactotrophs (Wynick et al., 1993). Thus, the possibility is raised that the changes observed in VIP/PHI, but perhaps also those for G $\Lambda \mathrm{L}, \mathrm{CCK}$, and DYN could play a trophic role after injury. Further experiments combining electron microscopy and immunocytochemistry as well as physiological studies are of importance to help unravel these functions. For example, at present we do not know whether these substance act at the cellular level within the injured cells or if they are released in order to exert their effects extracellularly.

In addition to the speculations made so far, all peptides studied in this report are well known for their role in the control of release of adenohypophysial hormones (Harris, 1951; Schally et al., 1973; McCann, 1982). For instance, oxytocin has been implicated in the regulatory control of prolactin (Lumpkin et al., 1983; Johnston and Negro-Vilar, 1988), luteinizing hormone (Johnston and Negro-Vilar, 1988), and ACTH (Spinedi and Negro-Vilar, 1984), and these hormones have been shown to vary their secretion after neurointermediate lobectomy (Fagin et al., 1982, 1985; Froehlich et al., 1985; Johnston et al., 1986; Murai and Ben-Jonathan, 1986, 1988; Raff et al., 1988). Functional interactions between VP and thyrotropin-releasing hormone as well as with corticotropin-releasing factor are also well documented (Gillies et al., 1982; Lumpkin et al., 1987).

Hypophysectomy not only axotomizes magnocellular neurosecretory cells, but also deprives parvocellular hypophysiotropic neurons of feedback influences exerted by hormones of the pituitary or their peripheral targets. For instance, it is known that low circulating levels of corticosterone, as are encountered following adrenalectomy or hypophysectomy, result in elevated expression of VP, but not $\mathrm{OXY}$, in parvocellular neurosecretory neurons and their terminals of the external zone of the median eminence (Swanson et al., 1986; Plotsky and Sawchenko, 1987; Sawchenko, 1987; Cunningham and Sawchenko, 1991). Therefore, some of the changes described in the present report could also be related to the disruption of hormonal feedback mechanisms due to the extraction of the adenohypophysis. In fact, our results suggest that both phenomena are occurring at the same time. Future studies using neural lobectomy with long survival times may separate the influence of axotomy from the effects induced by removal of anterior pituitary hormones.

In conclusion, our findings indicate that magnocellular hypothalamic neurons undergo a wide variety of changes in the median eminence after their axons have been transected. The changes in peptide expression after hypophysectomy exhibit a pattern that is specific for each substance (Fig. 10). These observations not only raise the possibility that the peptides studied could be related to a regenerative process, but they also suggest the necessity of several substances acting in a "coordinated" manner in order to allow regeneration. Further experiments are obviously needed to address these assumptions.

\section{References}

Antunes JI, Louis KM, Huang S, Zimmerman E, Carmel PW, Ferin M (1980) Section of the pituitary stalk in the rhesus monkey: morphological and endocrine observations. Ann Neurol 8:308-316.

Arvidsson U, Cullheim S, Ulfhake B, Hökfelt T, Terenius L (1989a)
Altered levels of calcitonin gene-related peptide (CGRP)-like immunoreactivity of cat lumbar motoneurons after chronic spinal cord transection. Brain Res 489:387-391.

Arvidsson U, Johnson H, Piehl F, Cullheim S, Hökfelt T, Risling M, Terenius L, Ulfhake B (1989b) Peripheral nerve section induces increased levels of calcitonin gene-related peptide (CGRP)-like immunoreactivity in axotomized motoneurons. Exp Brain Res 79:212216.

Barron KD (1983) Comparative observations on the cytologic reactons of central and peripheral nerve cells to axotomy. In: Spinal cord reconstruction (Bunge R, Reier PJ, eds), pp 7-40. New York: Raven.

Ben-Barak Y, Russell JT, Whitnall M, Ozato K, Gainer H (1984) Phylogenetic cross-reactivities of monoclonal antibodies produced against rat neurophysin. Cell Mol Neurobiol 4:339-349.

Ben-Barak Y, Russell JT, Whitnall M, Ozato K, Gainer H (1985) Neurophysin in the hypothalamo-neurohypophysial system. I. Production and characterization of monoclonal antibodies. $J$ Neurosci 5:81-97.

Bicknell RJ (1985) Endogenous opioid peptides and hypothalamic neuroendocrine neurones. J Endocrinol 107:437-446.

Billenstein DC, Lévèque TF (1955) The reorganization of the neurohypophysial stalk following hypophysectomy in the rat. Endocrinology 56:704-717.

Bodian D, Maren TH (1951) The effect of neuro- and adenohypophysectomy on retrograde degeneration in the hypothalamic nuclei of the rat. J Comp Neurol 94:485-514.

Bondy CA, Gainer H, Russell JT (1988) Dynorphin A inhibits and naloxone increases the electrically stimulated release of oxytocin but not vasopressin from terminals of the neural lobe. Endocrinology 122 : $1321-1327$

Bondy CA, Jensen RT, Brady LS, Gainer H (1989) Cholecystokinin evokes secretion and vasopressin from rat neural lobe independent of external calcium. Proc Natl Acad Sci USA 86:5198-5201.

Brenneman DE, Eiden LE (1986) Vasoactive intestinal peptide and electrical activity influence neuronal survival. Proc Natl Acad Sci USA 83:1159-1162.

Brownstein MJ, Mezey E (1986) Multiple chemical messengers in hypothalamic magnocellular neurons. Prog Brain Res 68:161-168.

Brownstein MJ, Russell JT, Gainer H (1980) Synthesis, transport, and release of posterior pituitary hormones. Science 207:373-384.

Burlet A, Zenon MC, Zankosic D, Coy D, Vaudry H (1983) Comparative immunocytochemical localization of corticotropin releasing factor (CRF-41) and neurohypophysial peptides in the brain of Brattleboro and Long-Evans rats. Neuroendocrinology 37:64-72.

Carithers J, Dellman H-D (1992) Regeneration of neural lobe-like neurovascular contact regions in explanted neural lobes placed in the hypothalamo-neurohypophysial tract in the lateral retrochiasmatic area. Brain Res 592:63-73.

Ceccatelli S, Tsuruo Y, Hökfelt T, Fahrenkrug J, Döhler K (1988) Some blood vessels in the rat median eminence are surrounded by a dense plexus of VIP/PHI immunoreactive nerves. Neurosci Lett 84 : 29-34.

Ceccatelli S, Fahrenkrug J, Villar MJ, Hökfelt T (1991) Vasoactive intestinal polypeptide/peptide histidine isoleucine (VIP/PHI) immunoreactive neuron systems in the basal hypothalamus of the rat with special reference to the portal vasculature. Neuroscience 43:483502.

Ceccatelli S, Lundberg J, Fahrenkrug J, Bredt DS, Snyder S, Hökfelt T (1993) Evidence for involvement of nitric oxide in the regulation of hypothalamic portal blood flow. Neuroscience 51:769-772.

Ch'ng JLC, Christofides ND, Anand P, Gibson SJ, Allen YS, Su HC Tatemoto U, Morrison JFB, Polak JM, Bloom SR (1985) Distribution of galanin immunoreactivity in the central nervous system and the responses of galanin-containing neuronal pathways to injury. Neuroscience 16:343-354.

Coons AH (1958) Fluorescent antibody methods. In: General cytochemical methods (Danielli JF, ed), pp 399-422. New York: Academic.

Cortés R, Ceccatelli S, Schalling M, Hökfelt T (1990a) Differential effects of intracerebroventricular colchicine administration on the expression of mRNAs for neuropeptides and neurotransmitter enzymes, with special emphasis on galanin: an in situ hybridization study. Synapse 6:369-391.

Cortés R, Villar MJ, Verhofstad A, Hökfelt T (1990b) Effects of central nervous system lesions on the expression of galanin: a comparative 
in situ hybridization and immunohistochemical study. Proc Natl Acad Sci USA 87:7742-7746.

Cortés R, Åman K, Arvidsson U, Terenius L, Frey P, Rehfeld JF, Walsh JH, Hökfelt T (1991) Immunohistochemical study of cholecystokinin peptide in rat spinal motoneurons. Synapse 9:103-110.

Cunningham ET, Sawchenko PE (1991) Reflex control of magnocellular vasopressin and oxytocin secretion. Trends Neurosci 14:406411.

Danilova OA, Polenov AL (1977) 'Gomori-posilive' neurosecretion in the rat after deafferentation of the medial basal hypothalamus. Cell Tissue Res 176:121-130.

Dellman H-D (1973) Degeneration and regeneration of neurosecretory systems. Int Rev Cytol 36:215-315.

Dellman H-D, Carithers J (1992) Development of neural-lobe-like neurovascular contact regions after intrahypothalamic transection of the hypothalamo-neurohypophysial tract. Brain Res 585:19-27.

Dellman H-D, Luc L-F, Bcllin SI (1987) Finc structural charactcristics of neurophysin-positive perivascular plexus that develop in the rat hypothalamus following interruption of the hypothalamo-neurohypophysial tract. Cell Tissue Res 247:137-143.

Dellman H-D, Lue L-F, Bellin SI, Ouassat M (1988) An immunohistochemical and fine-structural analysis of peptidergic hypothalamic neurosecretory axon regeneration into the leptomeninges of the rat. Brain Res 450:181-189.

Dumoulin FL, Raivich G, Streit WJ, Kreutzberg GW (1991) Differential regulation of calcitonin gene-related peptide (CGRP) in regenerating rat facial nucleus and dorsal root ganglion. Eur J Neurosci 3:338-342.

Elde R, Hökfelt T (1978) Distribution of hypothalamic hormones and other peptides in the brain. In: Frontiers in neuroendocrinology, Vol 5 (Ganong WF, Martini L, eds), pp 1-33. New York: Raven.

Fagin KD, Neill JD (1982) Involvement of the neurointermediate lobe of the pituitary gland in the secretion of prolactin and luteinizing hormone in the rat. Life Sci 30:1135-1141.

Fagin KD, Wiener SG, Dallman MF (1985) ACTH and corticosterone secretion in rats following removal of the ncurointermediatc lobe of the pituitary gland. Neuroendocrinology 40:352-362.

Fahrenkrug J, Pedersen JH (1984) Development and validation of specific radioimmunoassay for PHI in plasma. Clin Chim Acta 143: 183-192.

Fahrenkrug J, Schaffalitzky de Muckadell OB (1977) Radioimmunoassay of vasoactive intestinal polypeptide (VIP) in plasma. J Lab Clin Med 89:1379-1388.

Fahrenkrug J, Schaffalitzky de Muckadell OB (1978) Distribution of vasoactive intestinal polypeptide (VIP) in the porcine central nervous system. J Neurochem 31:1445-1451.

Froehlich JC, Neill MA, Ben-Jonathan N (1985) Interaction between the posterior pituitary and LHRH in the control of LH secretion. Peptides 6[Suppl 1]:127-131.

Frykman HM (1942) A quantitative study of the paraventricular nucleus and its alteration in hypophysectomy. Endocrinology 31:23-29.

Gaymann W, Martin R (1989) Immunoreactive galanin-like material in magnocellular hypothalamo-neurohypophysial neurons of the rat. Cell Tissue Res 255:139-147.

Gillies GE, Linton EA, Lowry PJ (1982) Corticotrophin releasing activity of the new CRF is potentiated several times by vasopressin. Nature 299:355-357.

Gressens P, Hill JM, Gozes I, Fridkin M, Brenneman DE (1993) Growth factor function of vasoactive intestinal peptide in whole mouse embryos. Nature 362:155-158.

Haas CA, Streit WJ, Kreutzberg GW (1990) Rat facial motoneurons express increased levels of calcitonin gene-related peptide mRNA in response to axotomy. J Neurosci Res 27:270-275.

Haegerstrand A, Jonzon B, Dalsgaard CJ, Nilsson J (1989) Vasoactive intestinal polypeptide stimulates cell proliferation and adenylate cyclase activity of cultured human keratinocytes. Proc Natl Acad Sci USA 86:5993-5996.

Harris GW (1951) Neural control of the pituitary gland. London: Arnold.

Herman JP, Marciano FF, Gash DM (1986) Vasopressin administration prevents functional recovery of the vasopressinergic neurosecretory system following neurohypophysectomy. Neurosci Lett 72:239 246.

Herman JP, Marciano FF, Wiegand SJ, Gash DM (1987) Selective cell death of magnocellular vasopressin neurons in neurohypophysial rats following chronic administration of vasopressin. J Neurosci 7:2564-2575.

Hökfelt T (1991) Neuropeptides in perspective: the last ten years. Neuron 7:867-879.

Hökfelt T, Fahrenkrug J, Ju G, Ceccatelli S, Tsuruo Y, Meister B, Mutt V, Rundgren M, Brodin E, Terenius L, Hulting A-L, Werner S, Björklund $\mathrm{H}$, Vale W (1987) Analysis of peptide histidine-isoleucine/ vasoactive intestinal polypeptide-immunoreactive neurons in the central nervous system with special reference to their relation to corticotropin releasing factor- and enkephalin-like immunoreactivities in the paraventricular hypothalamic nucleus. Neuroscience 23:827857.

Jessell T, Tsunoo A, Kanazawa I, Otsuka M (1979) Substance P: depletion in the dorsal horn of the rat spinal cord after section of the peripheral processes of primary sensory neurons. Brain Res 168:247259.

Johnson DG, Nogucira Araujo GMC (1981) A simplc method of reducing the fading of immunofluorescence during microscopy. J Immunol Methods 43:349-350.

Johnston CA, Negro-Vilar A (1988) Role of oxytocin secretion during proestrus and in different physiological or pharmacological paradigms. Endocrinology 122:341-350.

Johnston CA, Fagin KD, Alper RH, Negro-Vilar A (1986) Prolactin release after 5-hydroxytryptophan treatment requires an intact neurointermediate pituitary lobe. Endocrinology 118:805-810.

Johnston CA, Fagin KD, Negro-Vilar A (1990) Differential affect of neurointermediate lobectomy on central oxytocin and vasopressin. Neurosci Lett 113:101-106.

Kiss JZ (1985) Anatomical studies of cholecystokinin in neurons and pathways involved in neuroendocrine regulation. In: Annals of the New York Academy of Sciences, Vol 448, Neuronal cholecystokinin (Vanderhaegen J-J, Crawley JN, eds), pp 144-151. New York: New York Academy of Sciences.

Kreutzberg GW (1992) Acute normal reaction to injury. In: Repair and regeneration of the nervous system (Nicholls JG, ed), pp 57-69. Berlin: Springer.

Leng G, Bicknell RJ (1986) The neurohypophysis. In: Neuroendocrinology (Lightman SL, Everitt BJ, eds), pp 177-206. Boston: Blackwell.

Lieberman AR (1971) The axon reaction: a review of the principal features of perikaryal responses to axon injury. Int Rev Neurobiol 14:49-124.

Lumpkin MD, Samson WK, McCann SM (1983) Hypothalamic and pituitary sites of action of oxytocin to alter prolactin secretion in the rat. Endocrinology 112:1711-1717.

Lumpkin MD, Samson WK, McCann SM (1987) Arginine vasopressin as a thyrotropin-releasing hormone. Science 235:1070-1073.

Martin R, Geis R, Holl R, Schäfer M, Voigt KH (1983) Co-existence of unrelated peptides in oxytocin and vasopressin terminals of rat neurohypophysis: immunoreactive methionine 5-enkephalin, leucine 5-enkephalin, and cholecystokinin-like substance. Neuroscience 8:213227.

McCann SM, Ojeda SR (1982) The role of brain peptides in the control of anterior pituitary hormone secretion. In: Neuroendocrine perspectives (Müller EE, MacLeod RM, eds), pp 1-22. Amsterdam: Elsevier.

Meister B (1993) Gene expression and chemical diversity in hypothalamic neurosecretory neurons. Mol Neurobiol 7:87-110.

Meister B, Hökfelt T (1988) Peptide- and transmitter-containing neurons in the mediobasal hypothalamus and their relation to GABAergic systems: possible roles in control of prolactin and growth hormone secretion. Synapse 2:585-605.

Meister B, Ceccatelli S, Hökfelt T, Andén NE, Andén M, Theodorsson E (1989) Neuropeptides, neuropeptides and binding sites in the rat mediobasal hypothalamus: effects of monosodium glutamate (MSG) lesions. Exp Brain Res 76:343-368.

Meister B, Villar MJ, Ceccatelli S, Hökfelt T (1990) Localization of chemical messengers in magnocellular neurons of the hypothalamic supraoptic and paraventricular nuclei: an immunohistochemical study using experimental manipulations. Neuroscience 37:603-633.

Melander T, Hökfelt T, Rökaeus Å (1986a) Distribution of galaninlike immunoreactivity in the rat central nervous system. J Comp Neurol 248:475-517.

Melander T, Hökfelı T, Rökaeus Å, Cuello AC, Oertel WH, Verhofstad A, Goldstein M (1986b) Coexistence of galanin-like immunoreac- 
tivity with catecholamines, 5-hydroxytryptamine, GABA and neuropeptides in the rat CNS. J Neurosci 6:3640-3654.

Moll J, De Wied D (1962) Observations on the hypothalamo-posthypophysial system of the posterior lobectomized rat. Gen Comp Endocrinol 2:215-228.

Moore RY (1989) Cranial motor neurons contain either galanin- or calcitonin gene-related peptide-like immunoreactivity. J Comp Neurol 282:512-522.

Murai I, Ben-Jonathan N (1986) Chronic posterior pituitary lobectomy: prolonged elevation of plasma prolactin and interruption of cyclicity. Neuroendocrinology 43:453-458.

Murai I, Ben-Jonathan N (1988) Posterior pituitary lobectomy ablishes the suckling-induced rise in prolactin (PRL): evidence for a PRLreleasing factor in the posterior pituitary. Endocrinology 121:205211.

Nagy L, Köves K, Réthelyi M, Halász B (1983) Is the knife cut in the hypothalamus a permanent barrier to growth of nerve fibers?-an affirmative answer. Brain Res 268:354-358.

Piehl F, Arvidsson U, Johnson H, Cullheim S, Villar MJ, Dagerlind Å, Terenius L, Hökfelt T, Ulfhake B (1991) Calcitonin gene-related peptide (CGRP)-like immunoreactivity and CGRP mRNA in rat spinal cord motoneurons after different types of lesions. Eur J Neurosci 3:737-757.

Pincus DW, DiCicco BE, Black IB (1990) Vasoactive intestinal peptide regulates mitosis, differentiation and survival of cultured sympathetic neuroblasts. Nature 343:564-567.

Platt JL, Michael AF (1983) Retardation of fading and enhancement of intensity of immunofluorescence of $p$-phenylenediamine. J Histochem Cytochem 31:840-842.

Plotsky PM, Sawchenko PE (1987) Hypophysial-portal plasma levels, median eminence content, and immunohistochemical staining of corticotropin-releasing factor, arginine vasopressin, and oxytocin after pharmacological adrenalectomy. Endocrinology 120:1361-1369.

Raff H, Merrill DC, Skelton MM, Brownfield MS, Cowley AW Jr (1988) Control of adrenocorticotropin secretion and adrenocortical sensitivity in neurohypophysectomized conscious dogs: effects of acute and chronic vasopressin replacement. Endocrinology 122:1410-1418.

Raisman G (1973) Electron microscopic studies of the development of new neurohumoral contacts in the median eminence of the rat after hypophysectomy. Brain Res 55:245-265.

Rasmussen AT (1940) Effects of hypophysectomy and hypophysial stalk resection on the hypothalamic nuclei of animals and man. Res Publ Assoc Res Nerv Ment Dis 20:245-269.

Reeves WB, Andreoli TE (1992) The posterior pituitary and water metabolism. In: Williams textbook of endocrinology (Wilson JD, Foster DW, eds) pp 311-356. Philadelphia: Saunders.

Rökaeus $\Lambda$, Young WS III, Mezey E (1988) Galanin coexists with vasopressin in the normal rat hypothalamus and galanin's synthesis is increased in the Brattleboro (diabetes insipidus) rat. Neurosci Lett 90:45-50.

Said SI, Mutt V (1970) Polypeptide with broad biological activity: isolation from small intestine. Science 169:1217-1218.

Saika T, Senba E, Noguchi K, Sato M, Kubo T, Matsunaga T, Tohyama $M$ (1991) Changes in expression of peptides in rat facial motoneurons after facial nerve crushing and resection. Mol Brain Res 11:187196.

Sawchenko PE (1987) Adrenalectomy-induced enhancement of CRF and vasopressin immunoreactivity in parvocellular neurosecretory neurons: anatomic, peptide, and steroid specificity. J Neurosci 7:10931106.

Sawchenko PE, Swanson LW (1985) Relationship of oxytocin pathways to the control of neuroendocrine and autonomic function. In: Oxytocin, clinical and laboratory studies (Amico JA, Robinson AG, eds), pp 87-103. Amsterdam: Excerpta Medica.

Sawchenko PE, Swanson LW, Vale WW (1985) The distribution of growth hormone-releasing factor (GRF)-immunoreactivity in the central nervous system of the rat: an immunohistochemical study using antisera directed against rat hypothalamic GRF. J Comp Neurol 237: 100-115.

Schally AV, Arimura A, Kastin AJ (1973) Hypothalamic regulatory hormones. Science 179:341-350.

Scott PM, Knigge KM (1981) Immunocytochemistry of luteinizing hormone-releasing hormone, vasopressin and corticotropin following deafferentation of the basal hypothalamus of the male rat brain. Cell Tissue Res 219:245-262.
Shehab SAS, Atkinson ME (1986) Vasoactive intestinal polypeptide increases in areas of the dorsal horn of the spinal cord from which other neuropeptides are depleted following peripheral axotomy. Exp Brain Res 62:422-430.

Silverman A-J, Zimmerman EA (1983) Magnocellular neurosecretory system. Annu Rev Neurosci 6:357-380.

Skofitsch G, Jacobowitz D (1985) Immunohistochemical mapping of galanin-like neurons in the rat central nervous system. Peptides 6:509546.

Spinedi E, Negro-Vilar A (1984) Arginine vasopressin and adrenocorticotropin release: correlation between binding characteristics and biological activity in anterior pituitary dispersed cells. Endocrinology 114:2247-2251.

Strand FL, Rose KJ, Zuccarelli LA, Kume J, Alves SE, Antonawich FJ, Garrett LY (1992) Neuropeptide hormones as neurotrophic factors. Physiol Rev 71:1017-1046.

Stutinsky F (1951) Sur l'origine de la substance gomori-positive du complexe hypothalamo-hypophysaire. C R Soc Biol (Paris) 145:367370.

Swanson LW, Sawchenko PE (1983) Hypothalamic intergration: organization of the paraventricular and supraoptic nuclei. Annu Rev Neurosci 6:275-325.

Swanson LW, Sawchenko PE, Lind RW (1986) Regulation of multiple peptides in CRF parvocellular neurosecretory neurons: implications for the stress response. Prog Brain Res 68:169-190.

Vanderhaeghen JJ, Lotstra F, Vandesande F, Dierickx K (1981) Coexistence of cholecystokinin and oxytocin-neurophysin in some magnocellular hypothalamo-hypophyseal neurons. Cell Tissue Res 221: 227-231.

Villar MJ, Cortés R, Theodorsson E, Wiesenfeld-Hallin Z, Schalling M, Fahrenkrug J, Emson PC, Hökfelt T (1989) Neuropeptide expression in rat dorsal root ganglion cells and spinal cord after peripheral nerve injury with special reference to galanin. Neuroscience 33:587604.

Villar MJ, Meister B, Cortés R, Schalling M, Morris M, Hökfelt T (1990) Neuropeptide gene expression in magnocellular hypothalamic neurons of normal and hypophysectomized rats. A combined immunohistochemical and in situ hybridization study. Neuroscience 36: 181-199.

Villar MJ, Ceccatelli S, Hökfelt T (1991a) Transient induction of c-fos in rat magnocellular hypothalamic neurons after hypophysectomy. Neuroreport 2:703-706.

Villar MJ, Wiesenfeld-Hallin Z, Xu X-J, Cortés R, Thedorsson E, Hökfelt $T(199 \mathrm{lb})$ Galanin in primary sensory neurons: response to lesions. In: Wenner-Gren Center international symposium series, Vol 58, Galanin: a new multifunctional peptide in the neuro-endocrine system (Hökfelt T, Bartfai T, Jacobowitz D, Ottoson D, eds), pp 287 293. New York: Mcmillan.

Villar MJ, Wiesenfeld-Hallin Z, Xu X-J, Thedorsson E, Emson P, Hökfelt T (1991c) Further studies on galanin-, substance P-, and CGRPlike immunoreactivities in primary sensory neurons and spinal cord: effects of dorsal rhizotomies and sciatic nerve lesions. Exp Neurol $112: 29-39$.

Waynforth HB (1980) Experimental and surgical technique in the rat, pp 147-150. New York: Academic.

Wetsel WC, Fernstrom JD (1987) In vivo biosynthesis of arginine vasopressin and oxytocin in hypothalami from intact and hypophysectomized rats. Endocrinology 120:2562-2568.

Wynick D, Hammond PJ, Akinsaya KO, Bloom SR (1993) Galanin regulated basal and oestrogen-stimulated lactotroph function. Nature 364:529-532.

Young WS III (1992) Expression of oxytocin and vasopressin genes. J Neuroendocrinol 4:527-539.

Young WS III, Horváth S, Palkovits M (1990) The influences of hyperosmolality and synaptic inputs on galanin and vasopressin expression in the hypothalamus. Neuroscience 39:115-125.

Zamboni L, De Martino S (1967) Buffered acid formaldehyde: a new rapid fixative for electron microscopy. J Cell Biol 148A:35.

Zhang X, Verge V, Wiesenfeld-Hallin Z, Piehl F, Hökfelt T (1993) Expression of neuropeptides and neuropeptide mRNAs in spinal cord after axotomy in the rat, with special reference to motoneurons and galanin. Exp Brain Res 93:450-461. 